\title{
Extractive Fermentation for Recovery of Bacteriocin-Like Inhibitory Substances Derived from Lactococcus lactis Gh1 Using PEG2000/Dextran T500 Aqueous Two-Phase System
}

\author{
Roslina Jawan ${ }^{1,2, *(\mathbb{D})}$, Sahar Abbasiliasi ${ }^{3}{ }^{(D)}$, Joo Shun Tan ${ }^{4}$, Murni Halim ${ }^{1,5}{ }^{\mathbb{D}}$, Shuhaimi Mustafa ${ }^{6}$, Bin Hao Lee ${ }^{7}$, \\ Jia Sim Kwa ${ }^{7}$ and Arbakariya B. Ariff ${ }^{1,5, *}$
}

1 Bioprocessing and Biomanufacturing Research Centre, Faculty of Biotechnology and Biomolecular Sciences, Universiti Putra Malaysia, UPM Serdang 43400, Selangor, Malaysia; murnihalim@upm.edu.my

2 Biotechnology Programme, Faculty of Science and Natural Resources, Universiti Malaysia Sabah, Jalan UMS, Kota Kinabalu 88400, Sabah, Malaysia

3 Halal Products Research Institute, Universiti Putra Malaysia, UPM Serdang 43400, Selangor, Malaysia; upmsahar@yahoo.com

4 School of Industrial Technology, Universiti Sains Malaysia, Gelugor 11800, Pulau Pinang, Malaysia; jooshun@usm.my

5 Department of Bioprocess Technology, Faculty of Biotechnology and Biomolecular Sciences, Universiti Putra Malaysia, UPM Serdang 43400, Selangor, Malaysia

6 Department of Microbiology, Faculty of Biotechnology and Biomolecular Sciences, Universiti Putra Malaysia, UPM Serdang 43400, Selangor, Malaysia; shuhaimi@upm.edu.my

Citation: Jawan, R.; Abbasiliasi, S.; Tan, J.S.; Halim, M.; Mustafa, S.; Lee, B.H.; Kwa, J.S.; Ariff, A.B. Extractive Fermentation for Recovery of Bacteriocin-Like Inhibitory

Substances Derived from Lactococcus lactis Gh1 Using PEG2000/Dextran T500 Aqueous Two-Phase System. Fermentation 2021, 7, 257. https://doi.org/10.3390/ fermentation7040257

Academic Editor: Jae-Hyung Mah

Received: 23 July 2021

Accepted: 27 October 2021

Published: 2 November 2021

Publisher's Note: MDPI stays neutral with regard to jurisdictional claims in published maps and institutional affiliations.

Copyright: (c) 2021 by the authors. Licensee MDPI, Basel, Switzerland. This article is an open access article distributed under the terms and conditions of the Creative Commons Attribution (CC BY) license (https:/ / creativecommons.org/licenses/by/ $4.0 /)$.
7 PNT Research Sdn. Bhd, Level 36, Menara Maxis, Kuala Lumpur City Centre 50088, Malaysia; binhao@pntresearch.com (B.H.L.); jass.kwa@pntresearch.com (J.S.K.)

* Correspondence: roslinaj@ums.edu.my (R.J.); arbarif@upm.edu.my (A.B.A.); Tel.: +60-08-832-0000 (ext. 101086) (R.J.); +60-38-946-7591 (A.B.A.)

\begin{abstract}
This work aimed to optimize the parameters affecting partitioning of a bacteriocin-like inhibitory substances (BLIS) from Lactococcus lactis Gh1 in extractive fermentation using polyethylene glycol (PEG)/dextran aqueous two-phase system (ATPS). This system was developed for the simultaneous cell cultivation and downstream processing of BLIS. Results showed that the molecular weight of PEG, PEG concentration, and dextran T500 affect the partition coefficient $(K)$, purification factor $(P F)$, and yield of BLIS partitioning. ATPS composed of $10 \%(w / w)$ PEG2000 and $8 \%(w / w)$ dextran T500, provided the greatest conditions for the extractive BLIS production. The $K(1.00 \pm 0.16), P F$ $(2.92 \pm 0.37)$ and yield $(77.24 \pm 2.81 \%)$ were increased at selected orbital speed $(200 \mathrm{rpm})$ and $\mathrm{pH}$ ( $\mathrm{pH} 7$ ). Sustainable growth of the cells in the bioreactor and repeated fermentation up to the eighth extractive batch were observed during the scale up process, ensuring a continuous production and purification of BLIS. Hence, the simplicity and effectiveness of ATPS in the purification of BLIS were proven in this study.
\end{abstract}

Keywords: extractive fermentation; bacteriocin; Lactococcus lactis; aqueous two-phase system; polyethylene glycol; dextran

\section{Introduction}

Globally, foodborne illness is still uncontrolled, and outbreaks can result in both health and economic losses [1]. Lactic acid bacteria (LAB) have a long history of use in the food and have a reputation of being 'generally recognized as safe' (GRAS). Due to their potential to inhibit or limit contamination by spoilage and/or disease microorganisms through the synthesis of diverse antimicrobial chemicals such as organic acid, hydrogen peroxide, ethanol, diacetyl, carbon dioxide, bacteriocin or antibiotic-like substances, LAB are extensively being used in the food industry [2]. Bacteriocins/bacteriocin-like inhibitory substances (BLIS) (unclassified bacteriocin with similar activity that can be identified using the same quantification methods as bacteriocin) are proteinaceous antimicrobial compounds 
with a variety of genetic origins that can aid the producer organism in outcompeting other bacterial species, whether post-translationally changed or not [3,4]. Bacteriocins have been used as bio preservatives against Listeria monocytogenes in foods and being studied as natural inhibitors of bacteria in the treatment of systemic diseases; in fact, bacteriocins are potential candidates to replace antibiotics as agents active against multidrug-resistant pathogens [5] via prevention/reduction of biofilm formation.

Among the LAB, Lactococcus lactis has evolved into an industrial cell factory for the production of bio-economically valuable items and is well recognized as a nisin-producing bacteria [6]. At present, only nisin has been approved by the Food and Drug Administration (FDA) for use in the food industry. It is active against Gram-positive bacteria including highly pathogenic and food spoilage microorganisms including Staphylococcus aureus and Listeria monocytogenes [7]. The global food additives market is expected to grow at a compound annual growth rate (CAGR) of 6\% between 2021 and 2026, reaching US\$ 131,040 million by the end of 2026 [8]. In our previous work, the BLIS activity produced by L. lactis Gh1 was in the range of $632.21 \pm 69.05 \mathrm{AU} / \mathrm{mL}$ to $834.15 \pm 28.55 \mathrm{AU} / \mathrm{mL}$, when grown in $\mathrm{BHI}$ medium at $30^{\circ} \mathrm{C}$. The BLIS activity of L. lactis Gh1 was more stable in $\mathrm{BHI}$ as compared to other media [9].

In biomanufacturing of any fermented product, over $80 \%$ of production costs are attributed for by downstream processing [10]. Extraction and purification of biomolecules such as protein needs to be economically viable and industrially proficient. The current practices, unfortunately, are both expensive, and labor- and time-intensive [11]. Aqueous two-phase system (ATPS) was listed as one of the possible state-of-the-art alternatives that are more cost-effective as compared to conventional purification methods such as ammonium sulphate precipitation, solvent-based precipitation, and chromatographybased techniques [12]. This system also offers a mild working condition, cost-effective, short-time consumption, and high recovery percentage of the final product [13]. The selective partitioning of the ATPS enabling biomolecular extraction in one step in contrast to conventional extraction techniques requiring several steps of operation with substantial loss of the target molecule in each step [14].

ATPS has environmentally safe, cheap, easy scaling, quick and effective techniques for biomolecules recovery and purification [14]. The polymers used in ATPS are nontoxic, biodegradable, and approved by the Food and Drug Administration (FDA) [15]. The use of an ATPS could be extended to the spontaneous purification in the fermentation process, namely extractive fermentation. Extractive fermentation in ATPS integrates both product formation and purification into a single step process, which facilitates instant recovery of the target biomolecules as it is formed [16]. ATPS has been broadly applied in downstream processing of compounds such as protein, enzymes, biopharmaceuticals products and natural products. The use of ATPS in the recovery and purification of bacteriocin has been previously described [11]. However, extractive fermentation for bacteriocin using ATPS so far have been reported only by Li et al. [17], who exploited the cultivation Lactococcus lactis in $\mathrm{PEG} / \mathrm{Na}_{2} \mathrm{SO}_{4}$ and $\mathrm{PEG} / \mathrm{MgSO}_{4} .7 \mathrm{H}_{2} \mathrm{O}$ aqueous two-phase medium, respectively.

Basically, ATPS can be formed by combining aqueous solutions of two incompatible polymers or from a mixing solution of polymer and salt above critical concentration. ATPS biomolecules are more evenly distributed between the phases and affected by many parameters relating to the phase system, physio-chemical properties of biomolecule and their interaction [18] and the partition behavior of target products is complex and difficult to predict. Poorly understood partition behavior is a major barrier in widely adaptation of ATPS on commercial levels for the purification of biomolecules [19]. Several approaches have been explored to assess the most important parameters determining partitioning behavior such as molecular weight of polymer, $\mathrm{pH}$, presence of neutral salts, and surface properties of biomolecules [20].

For the purification of BLIS from LAB using ATPS, a large number of works has been dedicated to the study of alternative constituents to form the phases. Yet, limited consideration has been given to extractive fermentation using PEG/dextran (polymer/polymer) as 
two-phase forming components. ATPS possess the required characteristic for process integration to improve its efficiency. In this study, in situ retrieval of BLIS using PEG/dextran based ATPS aptly integrates upstream and downstream process for continuous production and recovery of BLIS from the fermentation culture, thus reducing the time quotient of the whole process. Extractive fermentation also supports rapids exclusion of BLIS into separate phase, thus circumventing product inhibition and degradation during the fermentation. Moreover, the phase formation of a polymer-based component can be recycled and reused for further extraction, and this reduces the cost of polymers phase-forming component [21]. This study aims to establish an in situ continuous production and extraction approaches of BLIS by L. lactis Gh1 using the ATPS with PEG2000 and dextran T500.

\section{Materials and Methods}

\subsection{Media and Culture Conditions}

The strain used in this study was bacteriocins-like-inhibitory substance (BLIS) producing lactic acid bacterium (LAB), namely Lactococcus lactis Gh1, obtained from Bioprocessing and Biomanufacturing Research Centre, Universiti Putra Malaysia. This strain was a newly isolated LAB from a milk by-product of an Iranian traditional fermented milk by Abbasiliasi et al. [22] and it has been well characterized as probiotic strain in our previous work [23]. The cultivation of L. lactis Gh1 was carried out in $250 \mathrm{~mL}$ Erlenmeyer flask. About $1 \%(v / v)$ of overnight pre-grown inoculum was added to the $50 \mathrm{~mL}$ of brain heart infusion (BHI) (Merck, Darmstadt, German) broth and the culture was then maintained at agitation speed of $150 \mathrm{rpm}$ for $15 \mathrm{~h}$ at $30^{\circ} \mathrm{C}$ in an incubator shaker (Certomat ${ }^{\circledR}$ BS-1, Sartorius, Goettingen, Germany). For the fermentation that includes aqueous two-phase system (ATPS) top (PEG polymers), or bottom phase-forming reagents (ammonium sulphate, sodium citrate, sodium phosphate, and dextran T500), the fermentation broth was prepared by adding a single ATPS phase-forming additive ( $w / w$ basis) at different concentrations into the above-mentioned basic medium. Extractive fermentations were conducted in $250 \mathrm{~mL}$ Erlenmeyer flasks with $50 \mathrm{~g}$ of sterilized ATPS-containing fermentation medium or control (medium without phase-forming reagents). After the completion of fermentation, the culture was allowed to settle down at room temperature for $30 \mathrm{~min}$ or was centrifuged at $13,751 \times g$ for $10 \mathrm{~min}$ at $4{ }^{\circ} \mathrm{C}$. The volumes of both phases (top and bottom) were measured and recorded. Samples from each phase were appropriately diluted and analyzed for cell concentration, total protein, and BLIS activity.

\subsection{Effect of Different Phase-Forming Reagents on BLIS Production and Bacterial Cell Growth}

In ATPS phase-forming reagents, the viability of L. lactis Gh1 is critical. To measure cell survival and ability to secrete BLIS, the cell was cultured in various PEG molecular weights (2000, 4000, 6000, and 8000) and various bottom phase components (ammonium sulphate, sodium citrate, sodium phosphate, and dextran T500). Statistical analysis of the data was constructed using SPSS version 25.0 (SPSS Inc. Software, Chicago, IL, USA). A one-way analysis of variance (ANOVA) was employed to determine the significance of the mean of data (BLIS, protein concentration and cell concentration) at significance level of $0.05 \%$ corresponding to confidence level of $95 \%$ by using Duncan's multiple range test. Multivariate analysis of variance (MANOVA) was used to evaluate the interaction between two factors (type of PEG/bottom phase components and concentration). Results were presented as the mean \pm standard deviation of three values.

\subsection{Partitioning Behavior of BLIS in ATPS}

Preliminary screening of PEG molecular weights (2000, 4000, 6000 and 8000) (Sigma-Aldrich, St. Louis, MO, USA) and dextran T500 (average mol. wt. of 500,000 gmol ${ }^{-1}$ ) (Sigma-Aldrich, St. Louis, MO, USA) on the growth stability and BLIS stability was investigated using one-variable-at a-time approach (OVAT). The influence of PEG molecular weight, PEG concentrations, and dextran T500 concentrations (independent variables) on the BLIS partition coefficient $(K)$ was then optimized using a $2^{2}$ central composite design. 
The variables used were evaluated each at five coded levels $(-\alpha,-1,0,+1,+\alpha)$. A set of 13 experiments, which contained a factorial matrix, with five center points and star points to allow the estimation of the curvature, was performed. The range and levels of the components evaluated in this study are given in Table 1 . The mean squares values were calculated by dividing the sum of the squares of each variation source by their degrees of freedom, and a 95\% confidence level $(\alpha=0.05)$ was used to determine the statistical significance in all analyses.

Table 1. Factor levels of the $2^{2}$ central composite design to study the partitioning of BLIS in ATPS.

\begin{tabular}{|c|c|c|c|c|c|c|}
\hline \multirow{2}{*}{$\begin{array}{l}\text { Variable } \\
(\%, w / v)\end{array}$} & \multirow{2}{*}{ Symbol } & \multicolumn{5}{|c|}{ Coded Values } \\
\hline & & $-\alpha$ & -1 & 0 & +1 & $+\alpha$ \\
\hline PEG & $X_{1}$ & 7.0 & 8.0 & 10.0 & 12.0 & 13.0 \\
\hline $\begin{array}{l}\text { Dextran } \\
\text { T500 }\end{array}$ & $X_{2}$ & 5.0 & 6.0 & 8.0 & 10.0 & 11.0 \\
\hline
\end{tabular}

Note: PEG molecular weight: 2000, 4000, 6000 and 8000.

Design Expert ${ }^{\circledR}$ software version 12 (Stat-ease Inc., Minneapolis, MN, USA) was utilized to conduct the regression analysis and graphical trials. The quality of fit of the polynomial model equation expressed by the coefficient of determination $\mathrm{R}^{2}$ and analysis of variance (ANOVA) was also determined. The significance of the model, an optimum value of parameters was assessed by the determination coefficient, correlation coefficient and statistical testing of the model was made by Fisher's test [19].

\subsection{Effect of Orbital Agitation and $p H$ on Partitioning Performance of BLIS}

To evaluate the effect of orbital speed and $\mathrm{pH}$ on partition behavior, purification factor and production of BLIS in extractive fermentation, the orbital speed was varied from 100 to $250 \mathrm{rpm}$. The $\mathrm{pH}$ of the medium was adjusted at a range between $\mathrm{pH} 5$ to 9 , using either 1 molarity of hydrochloric acid $(\mathrm{HCl})$ or 1 molarity of sodium hydroxide $(\mathrm{NaOH})$ solution.

\subsection{Scale-Up of ATPS Extractive Fermentation to 2 L Stirred Tank Bioreactor}

ATPS extractive fermentation was scaled up to a $2 \mathrm{~L}$ stirred tank bioreactor (BIOSTAT, B. Braun Biotech International, Melsungen, Germany) with a working volume of $1 \mathrm{~L}$. During the fermentation, agitation speed was fixed at $200 \mathrm{rpm}$ without air sparging. The culture $\mathrm{pH}$ was monitored online using in situ sterilizable $\mathrm{pH}$ electrode (Mettler Toledo, Greifensee, Switzerland). Antifoam reagent (Silicon antifoam, Sigma-Aldrich, St. Louis, $\mathrm{MO}, \mathrm{USA}$ ) was added manually to suppress foaming during the fermentation. Temperature within the bioreactor vessel was controlled at $30{ }^{\circ} \mathrm{C}$.

\subsection{Repetitive Batch of ATPS Extractive Fermentation}

In ATPS extractive fermentation, BLIS separation and cell removal can both be done at the same time. BLIS was partitioned to the PEG-rich top phase after extraction and centrifugation, and the cells were precipitated in the dextran-rich bottom phase of the tube. Repetitive batch of ATPS extractive fermentation was carried out by recycling the phase-forming polymer and microbial cells, in an attempt to develop a fermentation system that fulfils long-term BLIS production and purification. As a result, this approach could be a cost-effective method for large-scale BLIS recovery. The cell-free top extraction phase was replaced with the fresh top phase for every $15 \mathrm{~h}$. The optimized formulation of PEG/dextran T500, $\mathrm{pH}$, orbital agitation and $\mathrm{pH}$ of the medium were used in this study. Top phase replacement is $10 \mathrm{~mL}$ of PEG2000 with $30 \mathrm{~mL}$ of fresh BHI broth at $\mathrm{pH} 7 \mathrm{pH}$ of medium was adjusted using either 1 molarity of $\mathrm{HCl}$ or 1 molarity of $\mathrm{NaOH}$ ) up to 8th cycle. Further then 8 batches of ATPS leads to reduced cell viability. The repetitive batch fermentation using only BHI broth (without PEG and dextran; only the cells being repeatedly recycled) was used as a control. Cell viability was checked using spread plate method every 4 th cycle to ensure the survivability of the cells. Overall idea of this study 
was reflected in Figure 1. Basically, to separate the partially purified BLIS from the system, the BLIS in top phase was precipitated using an acetone precipitation method [24] by adding $80 \%(v / v)$ of cold acetone and maintaining the sample at $-20{ }^{\circ} \mathrm{C}$ overnight. The precipitate was collected by centrifugation at $13,751 \times \mathrm{g}$ for $20 \mathrm{~min}$ at $4{ }^{\circ} \mathrm{C}$, then air dry under the laminar air flow for $2 \mathrm{~h}$ and resuspended in deionized water at ratio of 1:1.

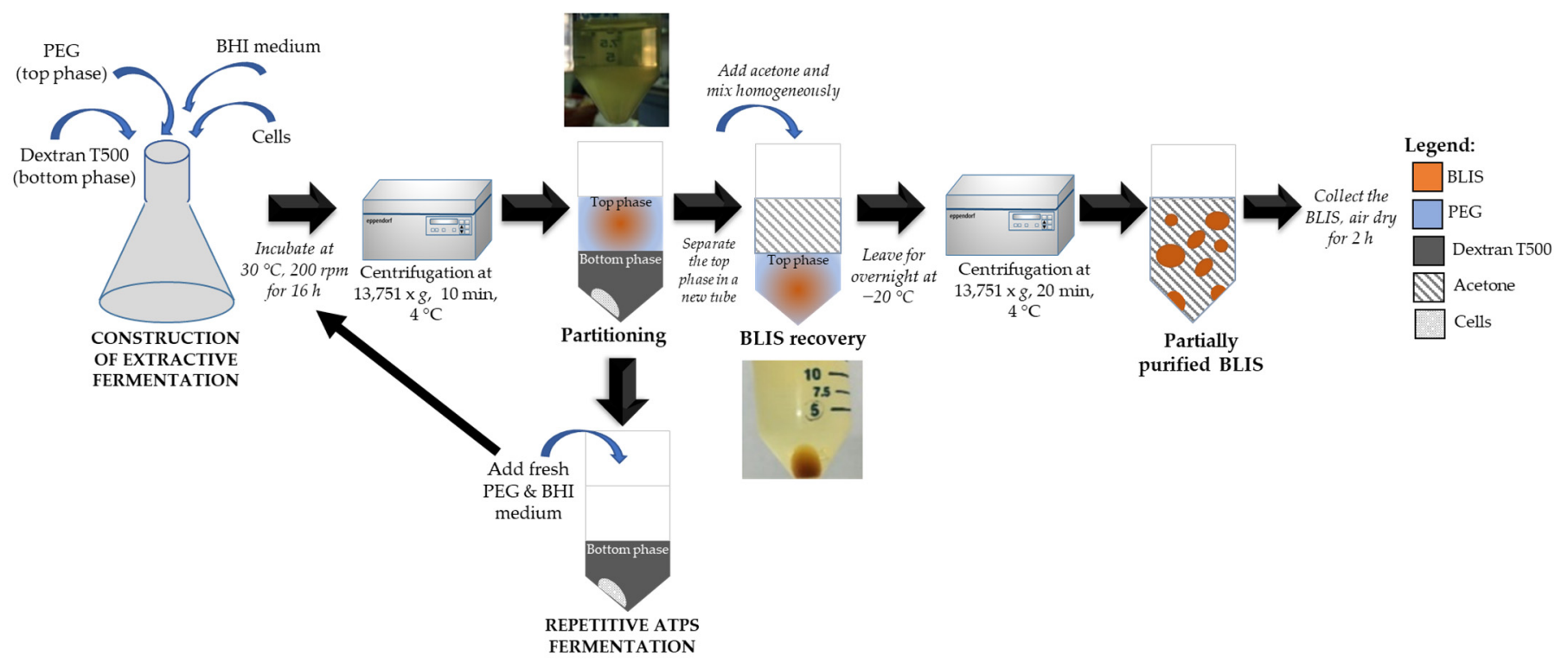

Figure 1. A schematic flow diagram for the process integration of BLIS production by L. lactis Gh1 with extractive aqueous two-phase fermentation process.

\subsection{Analytical Methods}

The cell viability was evaluated according to method as that defined in Jawan et al. [25]. Briefly, cell viability was examined using spread plate method and reported as colony forming units (CFU/mL). The surface of BHI agar plates was equally dispersed with decimal serial dilutions (ranging from $10^{1}$ to $10^{9}$ ) of each suspension in 100 milimolar sodium phosphate buffer ( $\mathrm{pH}$ 6.5) in triplicates. After incubation at $30^{\circ} \mathrm{C}$ for $24 \mathrm{~h}$, the number of viable cells was determined according to Equation (1):

$$
\mathrm{CFU} / \mathrm{mL}=\frac{\text { Number of colony } \times \text { dilution factor }}{\text { Volume of sample }(\text { in } \mathrm{mL})}
$$

Meanwhile, the optical density and the antimicrobial activity $(\mathrm{AU} / \mathrm{mL})$ of the cell free supernatant against Listeria monocytogenes ATCC 15, 313 was the same as that described in Jawan et al. [23]. After centrifugation at $13,751 \times \mathrm{g}$ for $10 \mathrm{~min}$ at $4{ }^{\circ} \mathrm{C}$, the cell pallets were washed and resuspended twice with $0.85 \%,(w / v) \mathrm{NaCl}$. Then, the turbidity was determined at $600 \mathrm{~nm}$ using a spectrophotometer (Biochrom Libra S12, Cambridge, UK). The optical density (OD) was converted into dry cell weight (DCW) from a standard curve using an experimentally predetermined factor of 0.26 where one OD unit was equivalent to 0.26 of DCW per volume $(\mathrm{g} / \mathrm{L})$. The antimicrobial activity $(\mathrm{AU} / \mathrm{mL})$ was quantitatively performed by the agar well diffusion method. Briefly, the supernatant $(100 \mu \mathrm{L})$ of L. lactis Gh1 was added in 6-mm agar plate wells that were previously seeded $(1 \%, v / v)$ with an active-growing L. monocytogenes ATCC 15313. The plates were then placed at $4{ }^{\circ} \mathrm{C}$ for $2 \mathrm{~h}$ to allow for good diffusion of the sample into the agar media prior to incubation at $37^{\circ} \mathrm{C}$ for $24 \mathrm{~h}$. The inhibition zone of the supernatant against the indicator bacteria was measured 
using an electronic caliper. The quantification of the antimicrobial activity was expressed as arbitrary units (AU) per milliliter (mL) and calculated using Equation (2):

$$
\text { BLIS activity }(\mathrm{AU} / \mathrm{mL})=\frac{\mathrm{A}_{\mathrm{z}}-\mathrm{A}_{\mathrm{w}}}{\mathrm{V}}
$$

where, $A_{z}=$ clear zone area $\left(\mathrm{mm}^{2}\right), A_{w}=$ well area $\left(\mathrm{mm}^{2}\right), V=$ volume of sample $(\mathrm{mL})$.

Quantification of total protein was performed as explained by Abbasiliasi et al. [24]. A total of $20 \mu \mathrm{L}$ of the sample was added to $200 \mu \mathrm{L}$ of Bradford reagent in a microtitre plate and incubated at $37^{\circ} \mathrm{C}$ for $15 \mathrm{~min}$. The absorbance was measured at $595 \mathrm{~nm}$.

\subsection{Determination of Relative Value, Volume Ratio, Partition Coefficient, Specific Activity,} Selectivity, and Yield

The relative values of BLIS activity or cell concentration were determined as the ratio of the BLIS activity $(\mathrm{AU} / \mathrm{mL}$ ) or cell concentration in the sample solution to that of control system (fermentation system without ATPS components). The partition coefficients of the BLIS ( $\left.K_{\text {Bacteriocin }}\right)$ or cell $\left(K_{\text {Cell }}\right)$ were calculated as the ratio of the BLIS activity in the top phase $\left(C_{T}\right)$ to the bottom phase $\left(C_{B}\right)$, respectively using Equation (3):

$$
K=C_{\mathrm{T}} / C_{B}
$$

Specific activity (SA), defined as the ratio between BLIS activity (AU) in the phase sample and the total protein concentration $(\mu \mathrm{g})$, was calculated using Equation (4):

$$
\mathrm{SA}\left(\frac{\mathrm{AU}}{\mu \mathrm{g}}\right)=\text { BLIS activity }(\mathrm{AU}) /[\text { Protein }](\mathrm{mg})
$$

Purification factor $(P F)$ described as the ratio of the BLIS specific activity (SA) in the top phase to the initial SA in the crude feedstock before partitioning using Equation (5) as suggested by Abbasiliasi et al. [26].

$$
P F=\mathrm{SA} \text { of phase sample/SA of crude feedstock }
$$

Selectivity $(S)$, defined as the ratio of BLIS partition coefficient $\left(k_{e}\right)$ to the protein partition coefficient $\left(k_{p}\right)$, was calculated using Equation (6) as described by Abbasiliasi et al. [26].

$$
S=k_{e} / k_{p}
$$

Volume ratio $\left(V_{R}\right)$, defined as the ratio of volume in the top phase $\left(V_{T}\right)$ to bottom phase $\left(\mathrm{V}_{\mathrm{B}}\right)$ was calculated using Equation (7):

$$
\mathrm{V}_{\mathrm{R}}=\mathrm{V}_{\mathrm{T}} / \mathrm{V}_{\mathrm{B}}
$$

In order to assess the recovery operation, the BLIS yield $\left(\mathrm{Y}_{\mathrm{T}}\right)$ in the top phase was calculated using Equation (8):

$$
\mathrm{Y}_{\mathrm{T}}(\%)=100 /\left(1+\left[1 /\left(\mathrm{V}_{\mathrm{R}} \times K_{\text {Bacteriocin }}\right)\right]\right)
$$

where $V_{R}$ is the volume ratio of the top phase to the bottom phase.

\section{Results}

\subsection{Selection of Polymer and Salt for Construction of ATPS and Their Influence on BLIS} Production and Bacterial Cell Growth

The growth compatibility of Lactococcus lactis Gh1 and bacteriocins-like-inhibitory substance (BLIS) production in different types and concentrations of polymer and salts/dextran are shown in Tables 2 and 3, respectively. In construction of aqueous two-phase system (ATPS), selecting an ideal molecular weight polymer is generally the crucial step. In this 
study, type and concentration of PEG markedly influence the cell concentration. While BLIS production significantly affected by molecular weight of polyethylene glycol (PEG).

Table 2. Growth of L. lactis Gh1 and production of BLIS in shake flask culture using BHI broth added with different types and concentrations of PEG. Temperature was maintained at $30^{\circ} \mathrm{C}$ and $\mathrm{pH}$ was not controlled.

\begin{tabular}{|c|c|c|c|c|}
\hline Type of PEG & $\begin{array}{l}\text { Concentration } \\
(\%, w / w)\end{array}$ & $\begin{array}{l}\text { BLIS Activity } \\
\text { (AU/mL) }\end{array}$ & $\begin{array}{c}\text { Protein } \\
\text { Concentration } \\
(\mu \mathrm{g} / \mathrm{mL})\end{array}$ & $\begin{array}{c}\text { Cell } \\
\text { Concentration } \\
(\mathrm{g} / \mathrm{L})\end{array}$ \\
\hline \multicolumn{2}{|c|}{ Control (BHI medium) } & $552.00 \pm 34.34^{\mathrm{cd}}$ & $83.65 \pm 0.122^{a}$ & $0.33 \pm 0.002^{\mathrm{a}}$ \\
\hline \multirow{4}{*}{ PEG2000 } & 5 & $577.15 \pm 17.43^{\mathrm{abcd}}$ & $32.00 \pm 0.032^{\text {cde }}$ & $0.26 \pm 0.003^{\mathrm{e}}$ \\
\hline & 10 & $580.40 \pm 8.15^{\mathrm{abcd}}$ & $10.59 \pm 0.013 \mathrm{hi}$ & $0.27 \pm 0.003^{d}$ \\
\hline & 15 & $580.39 \pm 1.16^{\mathrm{abcd}}$ & $6.77 \pm 0.020^{\mathrm{i}}$ & $0.22 \pm 0.008^{h}$ \\
\hline & 20 & $553.56 \pm 27.50 \mathrm{~cd}$ & $6.91 \pm 0.018^{i}$ & $0.19 \pm 0.002^{j}$ \\
\hline \multirow{4}{*}{ PEG4000 } & 5 & $556.73 \pm 16.07 \mathrm{~cd}$ & $34.07 \pm 0.016^{\mathrm{cd}}$ & $0.30 \pm 0.002^{c}$ \\
\hline & 10 & $538.76 \pm 64.70^{d}$ & $23.58 \pm 0.026^{\text {efg }}$ & $0.23 \pm 0.002 \mathrm{~g}$ \\
\hline & 15 & $568.93 \pm 12.72 \mathrm{bcd}$ & $17.15 \pm 0.030 \mathrm{gh}$ & $0.21 \pm 0.001^{h}$ \\
\hline & 20 & $580.42 \pm 15.13^{\mathrm{abcd}}$ & $19.44 \pm 0.024^{\mathrm{fgh}}$ & $0.18 \pm 0.001^{k}$ \\
\hline \multirow{4}{*}{ PEG6000 } & 5 & $590.60 \pm 45.66^{\mathrm{abcd}}$ & $39.86 \pm 0.082^{c}$ & $0.25 \pm 0.008^{\mathrm{f}}$ \\
\hline & 10 & $585.50 \pm 33.85^{\mathrm{abcd}}$ & $36.21 \pm 0.056^{\mathrm{cd}}$ & $0.22 \pm 0.001^{h}$ \\
\hline & 15 & $611.31 \pm 37.91$ abcd & $35.89 \pm 0.043^{\mathrm{cd}}$ & $0.20 \pm 0.001^{\mathrm{i}}$ \\
\hline & 20 & $622.92 \pm 16.69 \mathrm{abc}$ & $27.40 \pm 0.083$ def & $0.18 \pm 0.001^{k}$ \\
\hline \multirow{3}{*}{ PEG8000 } & 5 & $638.12 \pm 7.21 \mathrm{ab}$ & $55.96 \pm 0.036^{b}$ & $0.31 \pm 0.002^{b}$ \\
\hline & 10 & $645.97 \pm 37.43^{\mathrm{a}}$ & $49.36 \pm 0.030^{\mathrm{b}}$ & $0.27 \pm 0.003^{\mathrm{d}}$ \\
\hline & 15 & $626.60 \pm 50.17^{a b c}$ & $35.93 \pm 0.053^{\mathrm{cd}}$ & $0.23 \pm 0.004 \mathrm{~g}$ \\
\hline \multirow{3}{*}{\multicolumn{2}{|c|}{$\begin{array}{l}\text { Effect of type } \\
\text { Effect of concentration } \\
\text { Interaction }\end{array}$}} & $622.04 \pm 3.58^{a b c}$ & $26.35 \pm 0.031$ defg & $0.20 \pm 0.001^{\mathrm{i}}$ \\
\hline & & $\begin{array}{c}\mathrm{F}=8.94(\mathrm{~S}) \\
\mathrm{F}=0.14(\mathrm{NS})\end{array}$ & $\begin{array}{l}\mathrm{F}=90.14(\mathrm{~S}) \\
\mathrm{F}=47.42(\mathrm{~S})\end{array}$ & $\begin{array}{c}F=307.08(S) \\
F=1509.89(S)\end{array}$ \\
\hline & & $\mathrm{F}=0.61(\mathrm{NS})$ & $\mathrm{F}=4.46(\mathrm{~S})$ & $\mathrm{F}=74.78(\mathrm{~S})$ \\
\hline
\end{tabular}

Note: Data were obtained from three replicates. Data with same superscript alphabets were not differ with significant level at $p<0.05$ based on Duncan's multiple range test. S: significant; NS: not significant.

Table 3. Growth of L. lactis Gh1 and production of BLIS in shake flask culture using BHI added with different types and concentrations of salt/dextran T500. Temperature was maintained at $30{ }^{\circ} \mathrm{C}$ and $\mathrm{pH}$ was not controlled.

\begin{tabular}{|c|c|c|c|c|}
\hline $\begin{array}{c}\text { Type of Bottom } \\
\text { Phase Components }\end{array}$ & $\begin{array}{l}\text { Concentration } \\
(\%, w / w)\end{array}$ & $\begin{array}{l}\text { BLIS Activity } \\
\text { (AU/mL) }\end{array}$ & $\begin{array}{c}\text { Protein } \\
\text { Concentration } \\
(\mu \mathrm{g} / \mathrm{mL})\end{array}$ & $\begin{array}{c}\text { Cell } \\
\text { Concentration } \\
(\mathrm{g} / \mathrm{L})\end{array}$ \\
\hline \multirow[t]{2}{*}{ Control (BHI medium) } & & $624.57 \pm 4.77^{\mathrm{d}}$ & $73.68 \pm 0.010$ acbd & $0.34 \pm 0.005^{\mathrm{b}}$ \\
\hline & 5 & $618.67 \pm 3.57^{\mathrm{e}}$ & $73.93 \pm 0.058^{\mathrm{abcd}}$ & $0.37 \pm 0.002^{\mathrm{a}}$ \\
\hline \multirow{4}{*}{ Ammonium sulphate } & 10 & $602.84 \pm 23.58^{\mathrm{de}}$ & $55.58 \pm 0.106^{\text {cdef }}$ & $0.17 \pm 0.003 \mathrm{~g}$ \\
\hline & 15 & $711.80 \pm 6.25^{b c}$ & $50.42 \pm 0.028$ def & $0.17 \pm 0.001^{\mathrm{g}}$ \\
\hline & 20 & $216.05 \pm 7.08^{g}$ & $40.24 \pm 0.029^{f}$ & $0.002 \pm 0.001^{\mathrm{k}}$ \\
\hline & 5 & $558.31 \pm 2.30^{\mathrm{e}}$ & $73.86 \pm 0.140^{\mathrm{acbd}}$ & $0.22 \pm 0.003^{\mathrm{e}}$ \\
\hline \multirow{4}{*}{ Sodium citrate } & 10 & $342.05 \pm 15.84^{\mathrm{f}}$ & $54.66 \pm 0.070^{\mathrm{cdef}}$ & $0.01 \pm 0.0002^{\mathrm{i}}$ \\
\hline & 15 & $385.50 \pm 17.41^{\mathrm{f}}$ & $46.98 \pm 0.066^{\mathrm{ef}}$ & $0.01 \pm 0.0003^{j}$ \\
\hline & 20 & $0.00 \pm 0.00^{\mathrm{h}}$ & $74.38 \pm 0.161^{\mathrm{abcd}}$ & $0.00 \pm 0.00^{k}$ \\
\hline & 5 & $629.66 \pm 14.36^{d}$ & $77.72 \pm 0.136^{a b c}$ & $0.27 \pm 0.004^{c}$ \\
\hline \multirow{4}{*}{ Sodium phosphate } & 10 & $729.56 \pm 8.82^{d}$ & $90.70 \pm 0.188^{a}$ & $0.19 \pm 0.001^{\mathrm{f}}$ \\
\hline & 15 & $805.81 \pm 6.54^{\mathrm{a}}$ & $76.70 \pm 0.165^{a b c}$ & $0.17 \pm 0.001 \mathrm{~g}$ \\
\hline & 20 & $0.00 \pm 0.00^{\mathrm{h}}$ & $90.66 \pm 0.244^{a}$ & $0.00 \pm 0.0003^{\mathrm{k}}$ \\
\hline & 5 & $565.94 \pm 45.01^{\mathrm{e}}$ & $89.61 \pm 0.135^{\mathrm{ab}}$ & $0.22 \pm 0.001^{\mathrm{d}}$ \\
\hline \multirow{3}{*}{ Dextran T500 } & 10 & $694.40 \pm 38.39^{c}$ & $69.75 \pm 0.052$ abcde & $0.22 \pm 0.001^{\mathrm{d}}$ \\
\hline & 15 & $730.55 \pm 30.27^{b c}$ & $66.14 \pm 0.076^{\text {bcde }}$ & $0.17 \pm 0.001 \mathrm{~g}$ \\
\hline & 20 & $749.42 \pm 36.91^{b}$ & $67.54 \pm 0.015^{\text {abcde }}$ & $0.13 \pm 0.0002^{h}$ \\
\hline Effect of type & & $\mathrm{F}=392.83(\mathrm{~S})$ & $\mathrm{F}=11.58(\mathrm{~S})$ & $\mathrm{F}=14868.54(\mathrm{~S})$ \\
\hline Effect of concentration & & $\mathrm{F}=202.19(\mathrm{~S})$ & $\mathrm{F}=5.61(\mathrm{~S})$ & $\mathrm{F}=36171.86(\mathrm{~S})$ \\
\hline Interaction effect & & $\mathrm{F}=289.63(\mathrm{~S})$ & $\mathrm{F}=1.59(\mathrm{NS})$ & $\mathrm{F}=6241.57(\mathrm{~S})$ \\
\hline
\end{tabular}

Note: Data were obtained from 3 replicates. Data with same superscript alphabets were not differ with significant level at $p<0.05$ based on Duncan's multiple range $t$ S: significant; NS: not significant.

Among the PEG, PEG8000 at $10 \%(w / w)$ recorded the highest BLIS activity $(645.97 \pm 37.43 \mathrm{AU} / \mathrm{mL})$, while the highest protein concentration $(55.96 \pm 0.036 \mu \mathrm{g} / \mathrm{mL})$ 
and cell concentration $(0.31 \pm 0.002 \mathrm{~g} / \mathrm{L})$ was detected at 5\% $(w / w)$. All PEG at 5-15\% $(w / w)$ exhibited comparable cell concentration with only $6.06-33.33 \%$ reduction as compared to control (BHI medium), while the cell concentration was markedly reduced at $20 \%$ $(w / w)$. As the molecular weight of PEG has significant effect on all independent factors, therefore all PEGs were chosen for the subsequent response surface study to find out the optimal formulation for BLIS partitioning.

All types and concentrations of salts/dextran T500 significantly influenced the protein concentration, cell concentration and BLIS production of L. lactis Gh1, while interaction between type and concentration of salts has no effect on protein concentration. The highest BLIS activity $(805.81 \pm 6.54 \mathrm{AU} / \mathrm{mL})$ and protein concentration $(90.70 \pm 0.188 \mu \mathrm{g} / \mathrm{mL})$ was achieved with sodium phosphate at 15 and $10 \%(w / w)$, respectively. On the other hand, the highest cell concentration $(0.37 \pm 0.002 \mathrm{~g} / \mathrm{L})$ was obtained with ammonium sulphate at $5 \%$ $(w / w)$. However, cell concentration was significantly reduced or inhibited up to $4.12-100 \%$ as compared to control (BHI medium) at concentration higher than $5 \%(w / w)$ in all salts (sodium phosphate, sodium citrate, and ammonium sulphate) tested in this study. Remarkably, BLIS production (565.94-749.42 AU/mL) and cell concentration (0.13-0.22 g/L) were preserved at all concentrations of Dextran T500 indicating the compatibility of dextran T500 for BLIS production and cell concentration. Therefore, this polymer was used in the subsequent experiments.

\subsection{Influencing Factors on Partitioning Behavior of BLIS in ATPS}

Effect of three factors which are PEG molar mass, PEG concentrations, and dextran T500 concentrations, and their interactions on BLIS partition coefficient $(K)$ were evaluated using Central Composite Design (CCD). A total number of 13 experiments were employed for the response surface modelling, and the order of experiments was arranged randomly. The observed and predicted responses for the $K$ are depicted in Table 4 . The second-order polynomial equation derived by the Design Expert software were expressed by Equations in Table 5.

Results were assessed with various descriptive statistics such as the $p$-value, $F$-value, degree of freedom (DF), and the MS, mean square; the determination coefficient $\left(\mathrm{R}^{2}\right)$ of each coefficient was determined by Fisher's F-test and values of probability $>F$ (Table 6). A small probability value $(p<0.001)$ indicates that the model was highly significant and could be used to predict the response function accurately. Goodness-of-fit for the model was also evaluated by coefficients of determination $\mathrm{R}^{2}$ (correlation coefficient) and adjusted coefficients of determination $R^{2}$ adj. The large value of the correlation coefficient $R^{2}=0.9490$ (PEG2000), $\mathrm{R}^{2}=0.9257$ (PEG4000), and $\mathrm{R}^{2}=0.8928$ (PEG6000) respectively, indicated a high reliability of the model in predicting of partition coefficient $(K)$, by which 94.9, 92.6 and $89.3 \%$ of the response variability can be explained by the model. In all PEG sizes, $p$-value is less than the significance level and $F$-value indicating sufficient evidence to conclude that the regression model fits the data better than the model with no independent variables. In PEG8000/dextran T500 the BLIS tends to move to the dextran-rich bottom phase of the system producing low $K$ value (data not shown).

The highest experimental $K$ value (1.40) were recorded in PEG2000/8\% (w/v) of dextran T500 indicating the BLIS desirable in top phase of the system. In addition, the combination of PEG2000 and dextran T500 showed the highest $\mathrm{R}^{2}$ as compared to other two PEG molecular weight demonstrating smaller differences between the observed data and the fitted values. Therefore, PEG2000/8\% $(w / v)$ of dextran T500 was chosen for the further studies. 
Table 4. Central composite design for optimization of partition coefficient $(K)$ of extractive fermentation of L. lactis Gh1 using RSM.

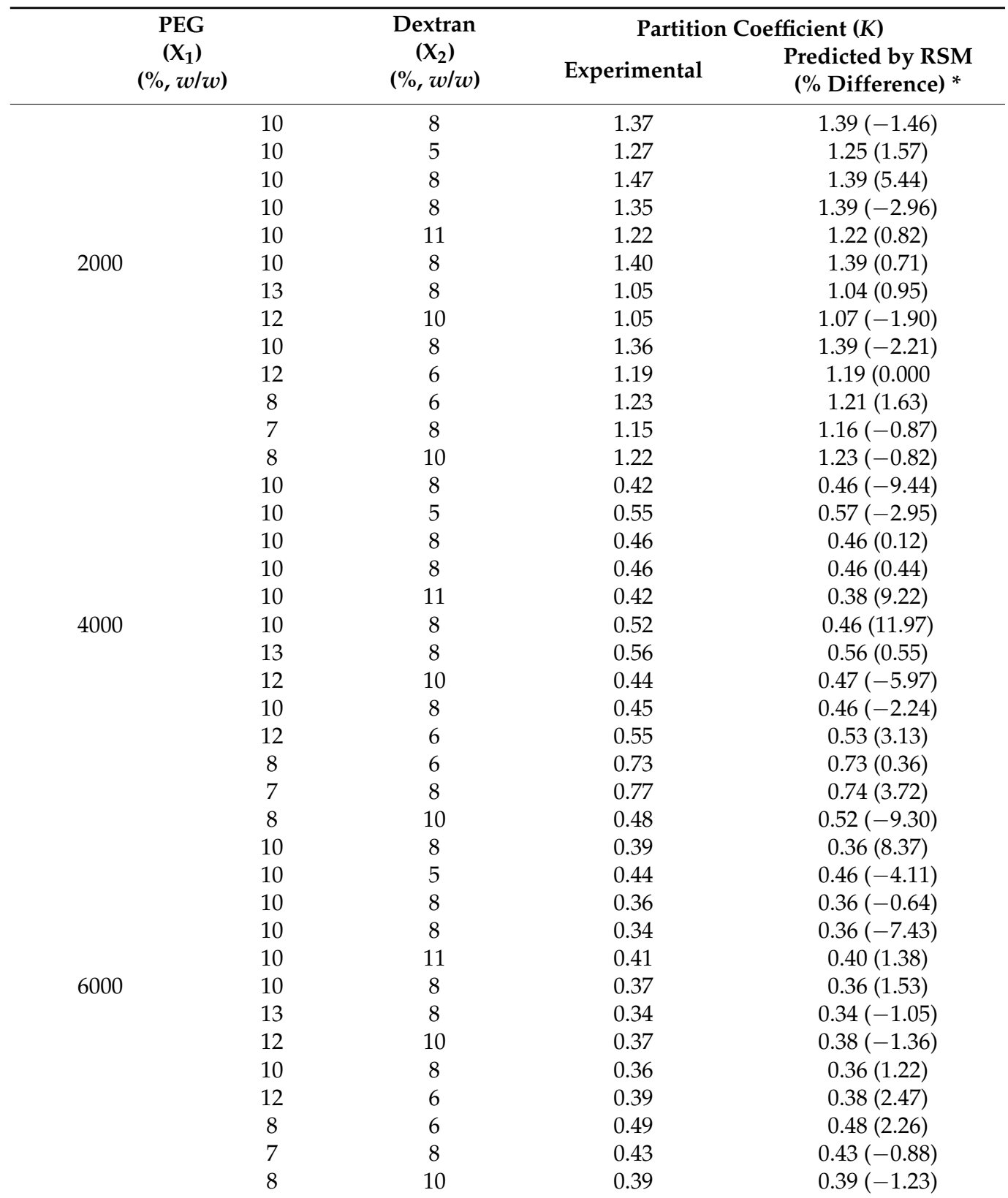

Note: * Percentages of differences was calculated by minus the observed $K$ with predicted by RSM and divided by observed $K$ value.

Table 5. Equations derived RSM for the prediction of the dependent variables for partition coefficient $(K)$ in term of coded factors.

\begin{tabular}{cc}
\hline Dependent Variables & Equation \\
\hline PEG2000: dextran & $+1.39-0.045 \mathrm{X}_{1}-0.026 \mathrm{X}_{2}-0.15 \mathrm{X}_{1}{ }^{2}-0.071 \mathrm{X}_{2}{ }^{2}-0.033 \mathrm{X}_{1} \mathrm{X}_{2}$ \\
PEG4000: dextran & $+0.46-0.064 \mathrm{X}_{1}-0.069 \mathrm{X}_{2}+0.095 \mathrm{X}_{2}{ }^{2}+4.969 \times 10^{3} \mathrm{X}_{2}{ }^{2}+0.038 \mathrm{X}_{1} \mathrm{X}_{2}$ \\
PEG6000: dextran & $+0.36-0.030 \mathrm{X}_{1}-0.021 \mathrm{X}_{2}+0.011 \mathrm{X}_{1}{ }^{2}+0.032 \mathrm{X}_{2}{ }^{2}+0.023 \mathrm{X}_{1} \mathrm{X}_{2}$ \\
\hline
\end{tabular}


Table 6. ANOVA for quadratic model of PEG: dextran T500.

\begin{tabular}{|c|c|c|c|c|c|}
\hline Source & SS & DF & MS & F-Value & $\operatorname{Prob}(p)>F$ \\
\hline \multicolumn{6}{|l|}{ PEG 2000} \\
\hline Model & 0.19 & 5 & 0.038 & 26.04 & $0.0002 * *$ \\
\hline Residual & 0.010 & 7 & $1.474 \times 10^{3}$ & & \\
\hline Lack of fit & $1.023 \times 10^{3}$ & 3 & $3.409 \times 10^{4}$ & 0.15 & $0.9266^{*}$ \\
\hline Pure error & $9.294 \times 10^{3}$ & 4 & $2.323 \times 10^{3}$ & & \\
\hline Total & 0.20 & 12 & & & \\
\hline $\mathrm{R}^{2}$ & 0.9490 & & & & \\
\hline Adj- $R^{2}$ & 0.9126 & & & & \\
\hline Pred-R ${ }^{2}$ & 0.8922 & & & & \\
\hline $\mathrm{CV}$ & 3.05 & & & & \\
\hline \multicolumn{6}{|l|}{ PEG 4000} \\
\hline Model & 0.14 & 5 & 0.028 & 17.43 & $0.0008^{* *}$ \\
\hline Residual & 0.011 & 7 & $1.596 \times 10^{3}$ & & \\
\hline Lack of fit & $5.630 \times 10^{3}$ & 3 & $1.877 \times 10^{3}$ & 1.35 & 0.3762 * \\
\hline Pure error & $5.544 \times 10^{3}$ & 4 & $1.386 \times 10^{3}$ & & \\
\hline Total & 0.15 & 12 & & & \\
\hline $\mathrm{R}^{2}$ & 0.9257 & & & & \\
\hline $\operatorname{Adj}-R^{2}$ & 0.8726 & & & & \\
\hline Pred-R ${ }^{2}$ & 0.6760 & & & & \\
\hline $\mathrm{CV}$ & 7.62 & & & & \\
\hline \multicolumn{6}{|l|}{ PEG 6000} \\
\hline Model & 0.020 & 5 & $4.088 \times 10^{3}$ & 11.66 & $0.0027^{* *}$ \\
\hline Residual & $2.454 \times 10^{3}$ & 7 & $3.506 \times 10^{4}$ & & \\
\hline Lack of fit & $7.465 \times 10^{4}$ & 3 & $2.488 \times 10^{4}$ & 0.58 & 0.6572 * \\
\hline Pure error & $1.708 \times 10^{3}$ & 4 & $4.270 \times 10^{4}$ & & \\
\hline Total & 0.023 & 12 & & & \\
\hline $\mathrm{R}^{2}$ & 0.8928 & & & & \\
\hline $\operatorname{Adj}-R^{2}$ & 0.8162 & & & & \\
\hline Pred-R ${ }^{2}$ & 0.6516 & & & & \\
\hline $\mathrm{CV}$ & 4.80 & & & & \\
\hline
\end{tabular}

\subsection{Effects of Model Parameters and Their Interactions}

The significance of each model parameter was determined by means of Fischer's $F$-value and $p$-value. The Design Expert software was used to produce three-dimensional (3D) response surfaces contour plots. The 3D-surfaced contour plots demonstrate the regression equation in order to improve reaction conditions and are the most useful way of showing the reaction system conditions.

In these diagrams, two factors have their response functions, while all other factors are at fixed levels. The results of the interactions between two independent variables (PEG molecular weight and dextran T500) and the dependent variable (partition coefficient, K) are shown in Figure 2. In PEG2000/dextran T500 ATPS, the response surface and contour plot show a surface with a maximum point, in which the $K$ increased when PEG concentration and dextran T500 increased up to a certain level and decreased with further increase of these variables. Maximum $K$ value (1.47) in these conditions as predicted, corresponding to PEG2000 at 10\% $(w / w)$ and dextran T500 at $8 \%,(w / w)$ (Figure 2A). Differently, the maximal $K$ value was obtained at the lowest concentration of PEG $(8 \%$, $w / w)$ and dextran T500 $(6 \%, w / w)$ in response surface of PEG4000/dextran T500 $(K=0.77)$, and PEG6000/dextran T500 $(K=0.49)$ (Figure 2B,C). 
(A)

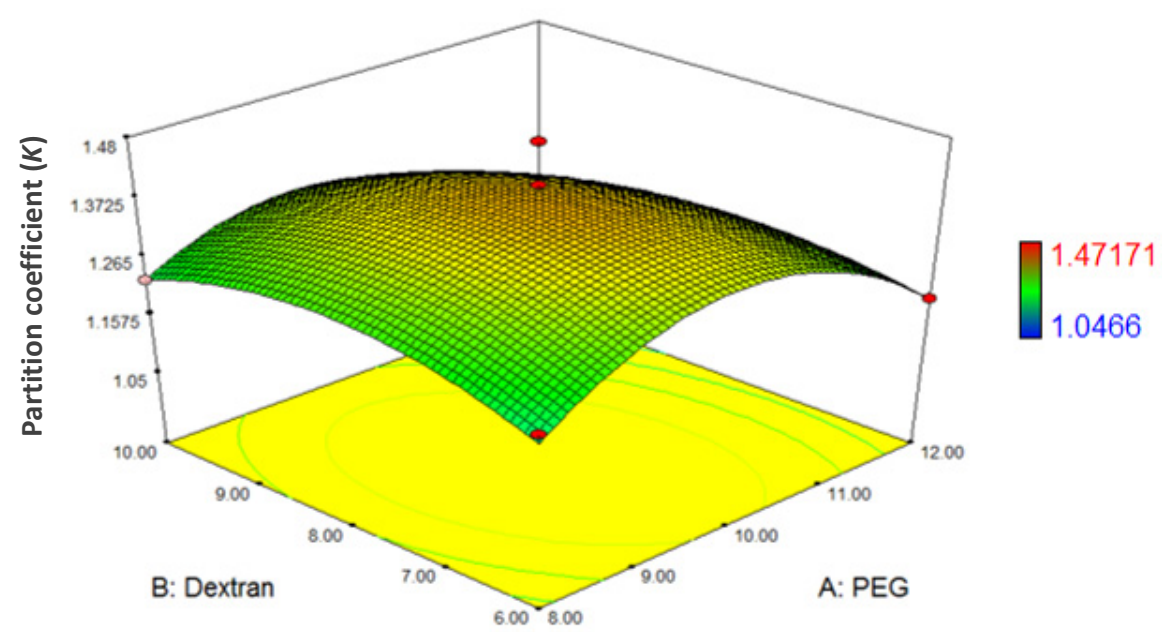

(B)

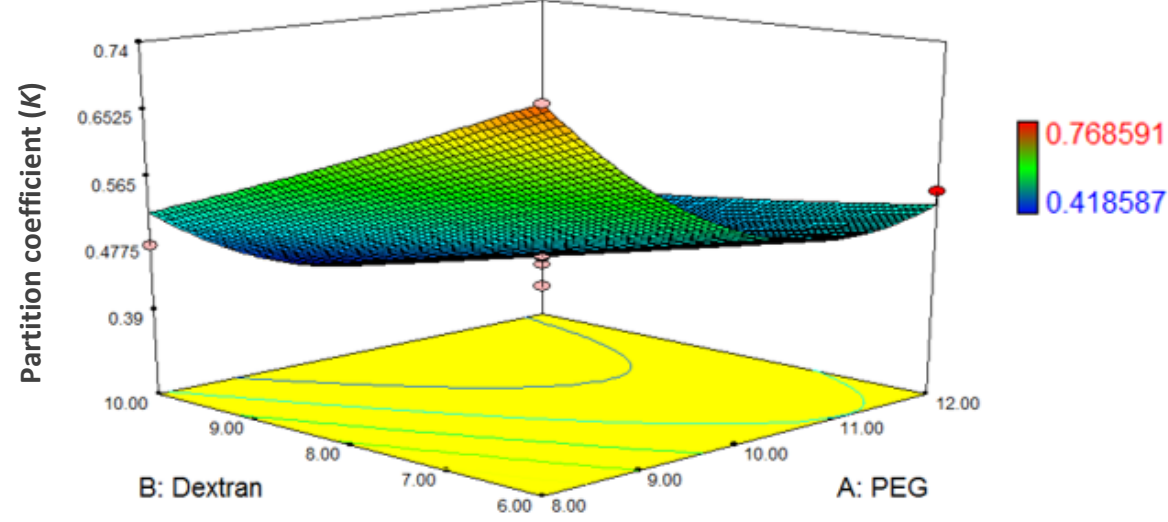

(C)

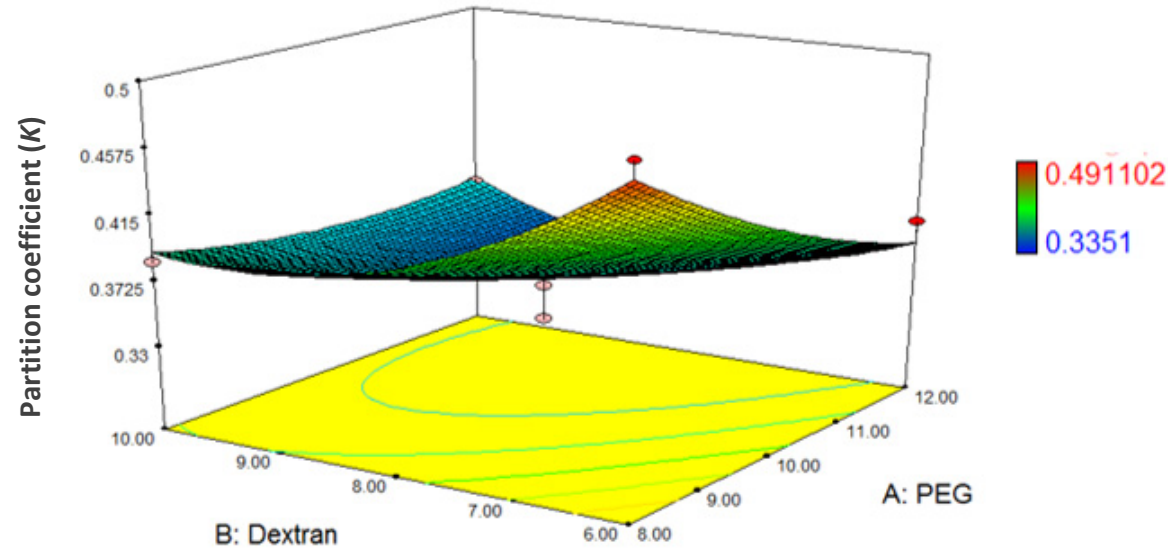

Figure 2. Surface plot obtained from optimization using RSM for the effect of various PEG molecular weight, dextran T500 and their mutual effect on BLIS partition coefficient $(K)$ of L. lactis Gh1. (A) PEG2000 and dextran T500; (B) PEG4000 and dextran T500; (C) PEG6000 and dextran T500. The different colors in the legend represent the respective range of $K$ value.

\subsection{The Prediction of the Optimum Condition of Partition Coefficient (K)}

To confirm the model's adequacy for predicting the maximum $K$ (response function), a new experiment based on the optimum levels, were carried out and the results were compared with the predicted results generated by the RSM as shown in Table 7. The predictive and experimental results at optimum levels are well agreed, which gives the model a great 
validity. Under the optimized condition which comprised of PEG2000 $(10 \%, w / w) /$ dextran $\mathrm{T} 500(8 \%, w / w)$ at $\mathrm{pH} 7$ and agitated at $200 \mathrm{rpm}$ the predicted $K$ value was 1.39 . The validation of the predicted model was done by conducting the experiment using the suggested condition resulting $K$ of 1.07 , close to the predicted value. Although the result shows the robustness of the model to predict the BLIS partitioning behavior in ATPS, a minimal difference (0.23) was still observed between experimental and predicted values, suggesting the model used in RSM can be further improved. Hence, to improve the prediction capability of the model, additional experiments such as refining the range of PEG2000/dextran T500 are required to cover the entire experimental space.

Table 7. Comparison of the predictive and the experimental result optimum values of partition coefficient $(K)$.

\begin{tabular}{cccc}
\hline Parameters & Predicted by RSM & Experimental & \% of Difference \\
\hline Purification factor $(P F)$ & 1.78 & 2.15 & -0.21 \\
Partition coefficient $(K)$ & 1.39 & 1.07 & 0.23 \\
Recovery/yield $(\%)$ & 73.97 & 76.28 & -0.03 \\
Cell concentration $(\mathrm{g} / \mathrm{L})$ & 0.37 & 0.22 & 0.40 \\
\hline
\end{tabular}

\subsection{Effect of Orbital Agitation and $p H$ on Partitioning of BLIS}

The effect of orbital agitation speed and $\mathrm{pH}$ on BLIS partitioning behavior are shown in Tables 8 and 9 , respectively. There was no significant difference $(p<0.05)$ in specific activity (SA) and purification factor (PF) between orbital speed tested. However, the highest SA $(19,530.09 \pm 2173.03)$ was recorded in $250 \mathrm{rpm}$. The highest $K(0.94 \pm 0.040)$, $P F(2.02 \pm 0.11)$ and yield $(76.46 \pm 0.77 \%)$ were observed in $200 \mathrm{rpm}$. Selectivity, $S$ was decreased with increasing orbital speed. Orbital speed at $150 \mathrm{rpm}$ attained the highest $S$ $(2.55 \pm 0.26)$ value. Differently, cell concentration value was increased with the increment of orbital speed. Cell concentration in $250 \mathrm{rpm}$ produced the maximum cell concentration $(0.22 \pm 0.01 \mathrm{~g} / \mathrm{L})$ and significantly higher $(p<0.5)$ than those obtained by other orbital speeds. Oxygen mass transfer rate was enhanced at high agitation speed, which in turn, enhanced cell concentration. As the highest $K, P F$ and yield was achieved at $200 \mathrm{rpm}$, this orbital speed was selected for the subsequent experiments.

In influence of $\mathrm{pH}$ on BLIS partitioning, there were no significant difference $(p<0.05)$ in $K$ and yield. The highest $K(1.00 \pm 0.16), S(2.06 \pm 1.34)$ and yield $(77.24 \pm 2.81 \%)$ values were noted in $\mathrm{pH}$ 7. SA and $P F$ were greatly affected by $\mathrm{pH}$, where the value decreased with increasing $\mathrm{pH}$. The highest SA $(21820.84 \pm 1900.45)$ and $P F(3.11 \pm 0.27)$ were obtained in lowest $\mathrm{pH}$ value $(\mathrm{pH} 5)$. Moreover, the concentration of cells is substantially affected by $\mathrm{pH}$ variation. The maximum cell concentration $(0.29 \pm 0.03 \mathrm{~g} / \mathrm{L})$ was found at the highest $\mathrm{pH}$ value $(\mathrm{pH} 9)$, which was significantly higher $(p<0.5)$ than other $\mathrm{pH}$ values. The $\mathrm{pH}$ 7 was chosen for the subsequent experiment as it contributed the highest $K, \mathrm{~S}$ and yield among the range of $\mathrm{pH}$ so far tested.

Table 8. Influence of orbital speed on BLIS partitioning behavior in extractive ATPS using PEG2000 $(10 \%, w / w) /$ dextran $\mathrm{T} 500(8 \%, w / w)$.

\begin{tabular}{|c|c|c|c|c|c|c|}
\hline Orbital Speed & $\begin{array}{l}\text { Specific Activity } \\
\text { (SA) }\end{array}$ & $\begin{array}{c}\text { Partition } \\
\text { Coefficient (K) }\end{array}$ & $\begin{array}{l}\text { Purification Factor } \\
\qquad(P F)\end{array}$ & $\begin{array}{l}\text { Selectivity } \\
\quad(S)\end{array}$ & $\begin{array}{c}\text { Yield } \\
(\%)\end{array}$ & $\begin{array}{c}\text { Cell } \\
\text { Concentration } \\
(\mathrm{g} / \mathrm{L})\end{array}$ \\
\hline 150 & $16,741.63 \pm 1079.75^{a}$ & $0.87 \pm 0.017^{\mathrm{ab}}$ & $1.76 \pm 0.11^{\mathrm{a}}$ & $2.55 \pm 0.26^{\mathrm{a}}$ & $75.03 \pm 0.37^{\mathrm{ab}}$ & $0.15 \pm 0.02^{b}$ \\
\hline 200 & $16,899.88 \pm 951.29^{a}$ & $0.94 \pm 0.040^{\mathrm{a}}$ & $2.02 \pm 0.11^{\mathrm{a}}$ & $1.76 \pm 0.29 \mathrm{ab}$ & $76.46 \pm 0.77^{a}$ & $0.16 \pm 0.01^{b}$ \\
\hline 250 & $19,530.09 \pm 2173.03^{a}$ & $0.80 \pm 0.032^{b}$ & $1.72 \pm 0.19^{a}$ & $1.38 \pm 0.33^{b}$ & $73.34 \pm 0.78^{\mathrm{b}}$ & $0.22 \pm 0.01^{\mathrm{a}}$ \\
\hline
\end{tabular}

Note: Data were obtained from 3 replicates. Data with same superscript alphabets were not differ with significant level at $p<0.05$ based on Duncan's multiple range test. 
Table 9. Influence of $\mathrm{pH}$ on BLIS partitioning behavior in extractive ATPS using PEG2000 $(10 \%, w / w) /$ dextran T500 $(8 \%, w / w)$.

\begin{tabular}{ccccccc}
\hline pH & $\begin{array}{c}\text { Specific Activity } \\
\text { (SA) }\end{array}$ & $\begin{array}{c}\text { Partition } \\
\text { Coefficient }(\boldsymbol{K})\end{array}$ & $\begin{array}{c}\text { Purification Factor } \\
(\boldsymbol{P F})\end{array}$ & $\begin{array}{c}\text { Selectivity } \\
(\boldsymbol{S})\end{array}$ & $\begin{array}{c}\text { Yield } \\
(\%)\end{array}$ & $\begin{array}{c}\text { Cell } \\
\text { Concentration } \\
(\mathbf{g} / \mathbf{L})\end{array}$ \\
\hline$*$ & $16707.71 \pm 1352.99^{\mathrm{bc}}$ & $0.83 \pm 0.10^{\mathrm{a}}$ & $2.38 \pm 0.19 \mathrm{~b}^{\mathrm{c}}$ & $1.08 \pm 0.45^{\mathrm{ab}}$ & $74.05 \pm 2.24^{\mathrm{a}}$ & $0.13 \pm 0.02^{\mathrm{c}}$ \\
$\begin{array}{c}\text { Control } \\
5\end{array}$ & $21820.84 \pm 1900.45^{\mathrm{a}}$ & $0.79 \pm 0.07^{\mathrm{a}}$ & $3.11 \pm 0.27^{\mathrm{a}}$ & $0.38 \pm 0.26^{\mathrm{b}}$ & $72.97 \pm 1.72^{\mathrm{a}}$ & $0.11 \pm 0.01^{\mathrm{c}}$ \\
6 & $19775.51 \pm 1306.68^{\mathrm{ab}}$ & $0.81 \pm 0.02^{\mathrm{a}}$ & $2.82 \pm 0.19^{\mathrm{ab}}$ & $0.96 \pm 0.16^{\mathrm{ab}}$ & $73.61 \pm 0.56^{\mathrm{a}}$ & $0.13 \pm 0.00^{\mathrm{c}}$ \\
7 & $20442.98 \pm 2606.24^{\mathrm{ab}}$ & $1.00 \pm 0.16^{\mathrm{a}}$ & $2.92 \pm 0.37^{\mathrm{ab}}$ & $2.06 \pm 1.34^{\mathrm{a}}$ & $77.24 \pm 2.81^{\mathrm{a}}$ & $0.12^{\mathrm{a}} \pm 0.02^{\mathrm{c}}$ \\
8 & $15535.43 \pm 1087.32^{\mathrm{c}}$ & $0.91 \pm 0.15^{\mathrm{a}}$ & $2.22 \pm 0.16^{\mathrm{c}}$ & $0.93 \pm 0.28^{\mathrm{ab}}$ & $75.55 \pm 3.05^{\mathrm{a}}$ & $0.24 \pm 0.00^{\mathrm{b}}$ \\
9 & $12697.92 \pm 1215.92^{\mathrm{c}}$ & $0.85 \pm 0.01^{\mathrm{a}}$ & $1.81 \pm 0.17^{\mathrm{c}}$ & $1.20 \pm 0.38^{\mathrm{ab}}$ & $74.62^{\mathrm{a}} \pm 0.13^{\mathrm{a}}$ & $0.29 \pm 0.03^{\mathrm{a}}$ \\
\hline
\end{tabular}

Note: * Control is BHI broth without any pH changes (pH value of BHI broth: 7.36). Data were obtained from three replicates. Data with same superscript alphabets were not differ with significant level at $p<0.05$ based on Duncan's multiple range test.

\subsection{Scale-Up of ATPS in 2 L Stirred Tank Bioreactor}

The comparison of $K$ value, $P F$, and yield of BLIS from L. lactis Gh1 for aqueous two-phase fermentation in an Erlenmeyer flask and 2 L bioreactor are shown in Figure 3. To understand the production profile of BLIS in greater detail and to confirm the validity of the optimization study, an attempt was made for the possibility to scale-up the process. The effectiveness of the operation was confirmed in a $2 \mathrm{~L}$ stirred tank bioreactor under conditions similar to the optimal $\mathrm{pH}(\mathrm{pH} 7)$ and orbital agitation speed (200 rpm) obtained in the shake flask. The overall $K, P F$ and yield value of extractive fermentation obtained in the bioreactor were higher than those obtained in shake flask fermentation. The maximum $K, P F$ and yield values of both extractive fermentation in Erlenmeyer flask $(K=0.98$, $P F=1.23$, and yield $=69.60 \%)$ and $2 \mathrm{~L}$ bioreactor $(K=0.93, P F=1.93$, and yield $=68.34 \%)$ were not much different.

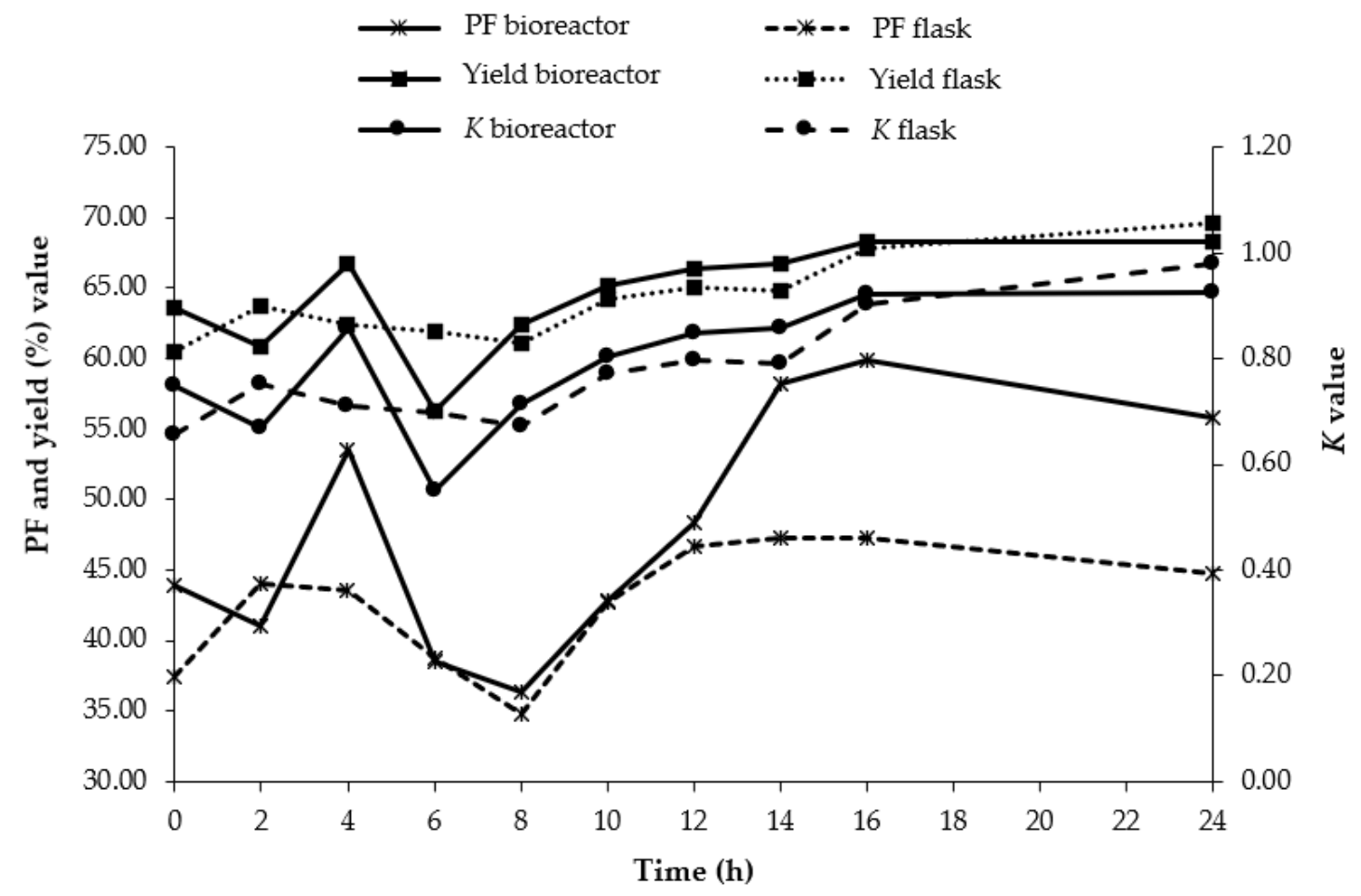

Figure 3. Comparison of $K$ value, $P F$ and yield of BLIS from L. lactis Gh1 for aqueous two-phase fermentation in $2 \mathrm{~L}$ bioreactor and Erlenmeyer flask. At the optimum conditions of a 10\% (w/w) PEG2000, 8\% (w/w) dextran T500, pH 7 and agitated at $200 \mathrm{rpm}$ at $30^{\circ} \mathrm{C}$. (......) ATPS in Erlenmeyer flask, and (__ ATPS in 2 L bioreactor. 
The cell viability of $L$. lactis Gh1 during homogeneous, and aqueous two-phase fermentation both in an Erlenmeyer flask and a bench-scale bioreactor were compared (Figure 4). A higher cell viability was obtained from homogeneous fermentation compared to that of extractive fermentation in both Erlenmeyer flask and a bench-scale bioreactor. The presence of polymers (i.e., PEG and dextran) reduced the growth rate of L. lactis Gh1. However, the sustainable cells growth was obtained in aqueous two-phase fermentation in bioreactor make the repetitive fermentation in a large scale possible.

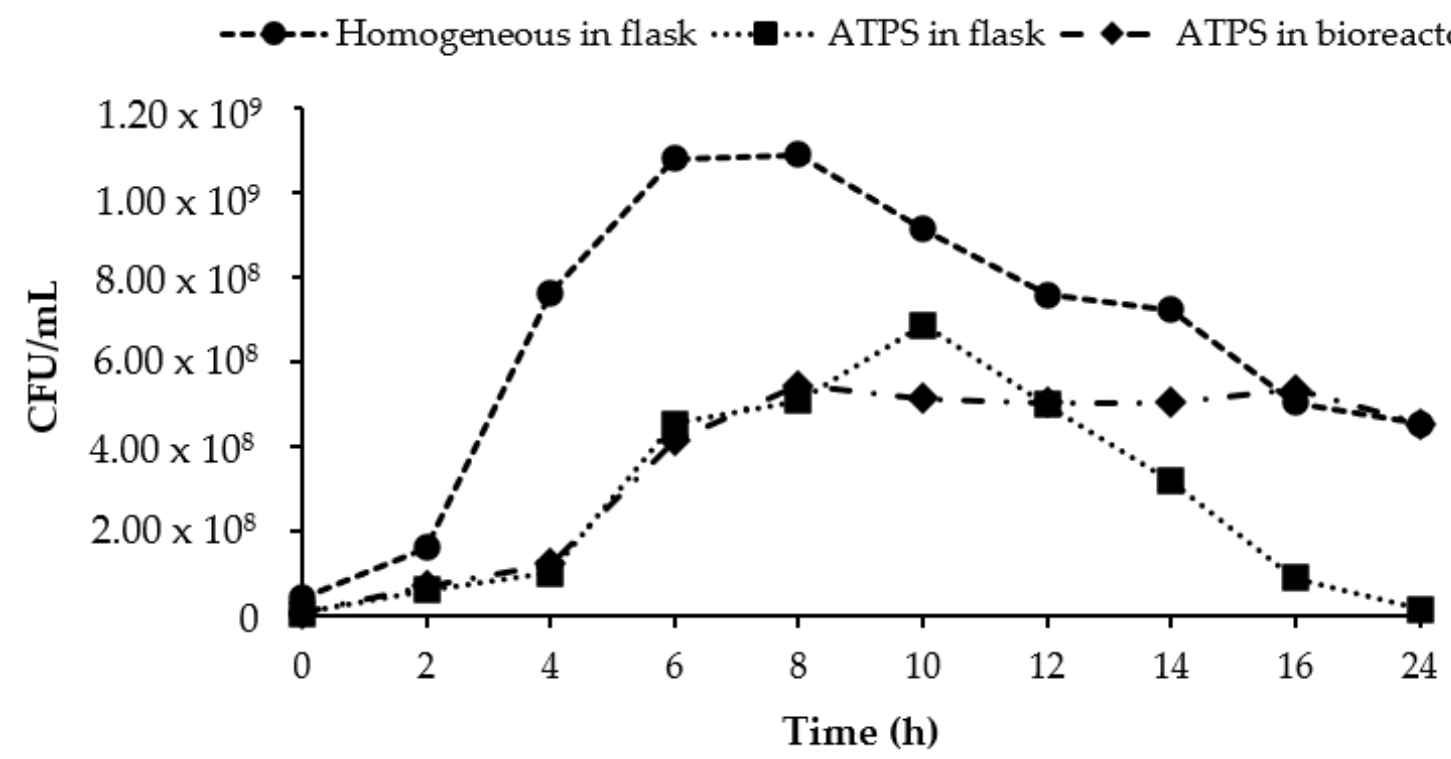

Figure 4. Comparison of the cell viability of L. lactis Gh1 for homogeneous and aqueous two-phase fermentations in an Erlenmeyer flask and a $2 \mathrm{~L}$ bioreactor. The cells were grown in the different fermentation environments (Erlenmeyer flask and batch bioreactor) and media, either with or without polymer were assayed and compared.

The growth pattern of L. lactis Gh1 in extractive fermentation exhibited the same pattern as homogeneous culture in both bioreactor and shake flask. The exponential phase was started after $2 \mathrm{~h}$ to $6 \mathrm{~h}$ of fermentation and the maximum viability was observed after $8 \mathrm{~h}$ while in flask the highest cell number shifted to $\mathrm{h}-10$. Prolonged ATPS-fermentation in the bioreactor preserves the high concentration of cells, while the cells enter the phase of death both in the flask ATPS and in the flask homogeneous culture. Maximum cell number of L. lactis Gh1 $\left(1.09 \times 10^{9} \mathrm{CFU} / \mathrm{mL}\right)$ obtained in the homogeneous culture in flask was about $36-50 \%$ higher as compared to both ATPS fermentation in flask $\left(6.87 \times 10^{8} \mathrm{CFU} / \mathrm{mL}\right)$ and in bioreactor $\left(5.43 \times 10^{8} \mathrm{CFU} / \mathrm{mL}\right)$.

\subsection{Repetitive ATPS Fermentation in an Erlenmeyer Flask}

The results of repetitive batch of extractive fermentation of ATPS are shown in Figure 5. Eight cycles of consecutive batch fermentations were conducted at conditions based on the previous optimized partitioning parameters. The viability of the cells was remained after the 8 th batch $\left(7.35 \times 10^{8} \mathrm{CFU} / \mathrm{mL}\right)$ of the repetitive ATPS fermentation. The number of cells in homogenous culture was reduced after four cycles of repetitive fermentation at $1.06 \times 10^{9} \mathrm{CFU} / \mathrm{mL}$. This result evidenced the benefit of ATPS in protecting the cells during the production and partitioning of BLIS and showed that the long-term L. lactis Gh1 cell growth could be supported by the ATPS extractive fermentation. BLIS was steadily produced during the entire course of repetitive batch fermentation up to 8th cycle in both ATPS and homogenous culture. The maximum BLIS activity obtained in ATPS was 1.47 times higher than that obtained in homogenous culture. 


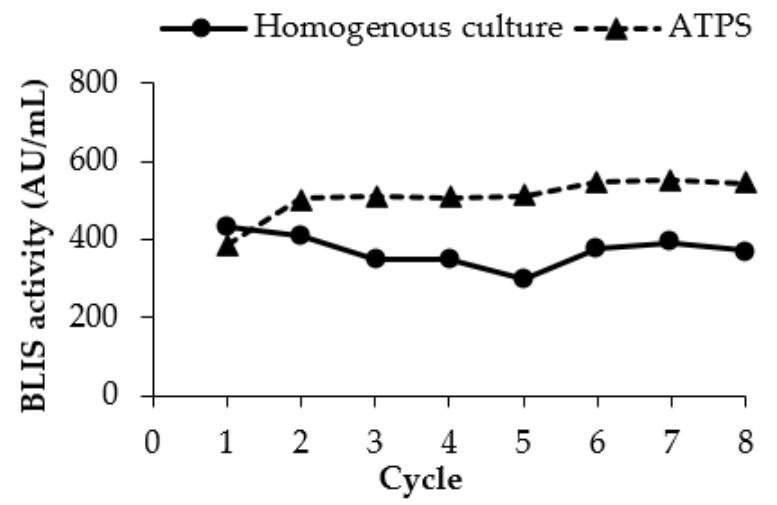

(A)

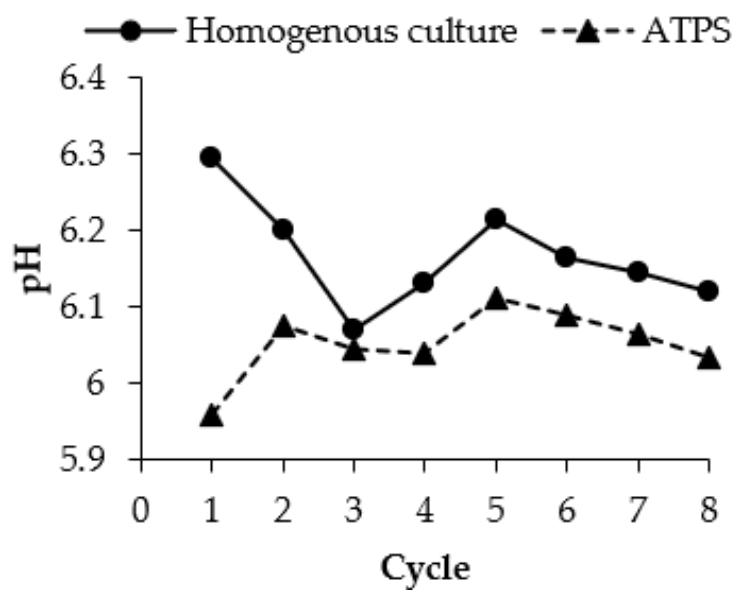

(C)

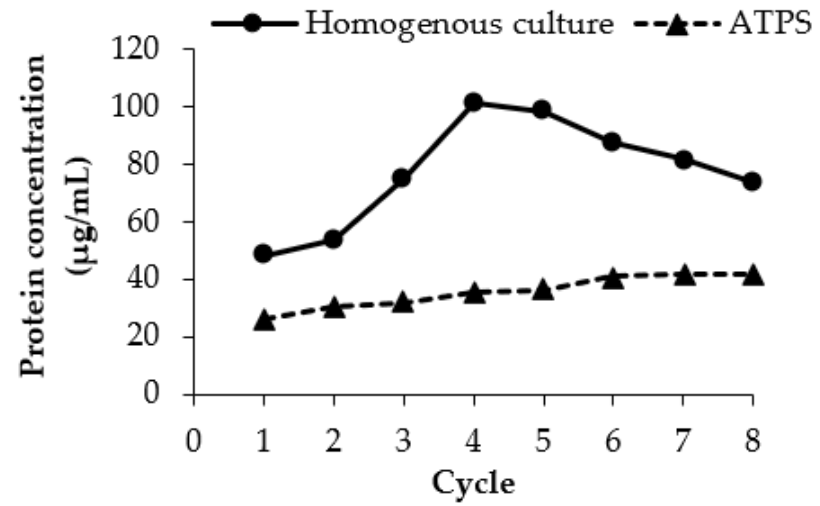

(B)

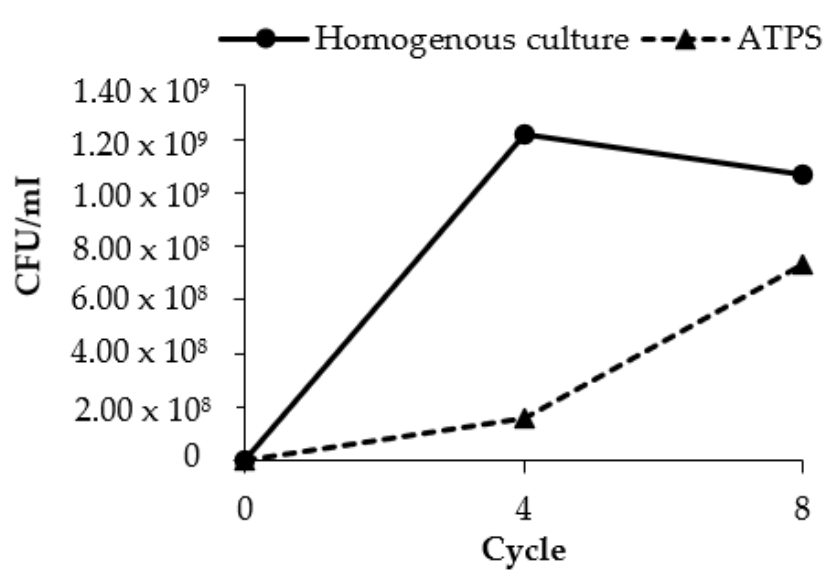

(D)

Figure 5. Repetitive batch of extractive fermentation of ATPS in Erlenmeyer flask. (A) BLIS activity; (B) protein concentration; (C) final $\mathrm{pH}$ (top phase); (D) cell viability (CFU/mL). Repetitive batch of BLIS fermentation was conducted in an ATPS composed of $10.0 \%(w / w)$ PEG 2000 and $8.0 \%(w / w)$ dextran T500. The top extraction phase was removed out from the culture system after $15 \mathrm{~h}$ of incubation and was replaced with the fresh top phase. (......) indicated ATPS and (__) indicated homogenous culture.

\section{Discussion}

Purified bacteriocins can reduce the number of pathogens or change the composition of intestinal microbiota in animal models. The ability of pure nisin was proven to influence the composition of intestinal microbiota in human flora-associated rats [27]. Another report shows that purified BLIS from Lactobacillus bulgaricus FTDC 1211 is necessary to inhibit Staphylococcus aureus. In terms of disease control, the use of purified bacteriocin is superior to the use of bacteria to produce bacteriocins. Hence, purification of bacteriocin is mandatory for food and medical application [28].

Extractive fermentation or in situ product recovery is the process in which aqueous two-phase system (ATPS) is integrated with bioconversion to overcome the low product yield. Low productivity is one of the most commonly observed issue in biotechnological processes because of inhibition, toxicity and instability of the end-product [29]. Therefore, about $60-90 \%$ cost of a biological process is expended in downstream processing. However, a high end-product concentration is feasible by extractive fermentation, because of low interfacial tension, continuous mode, selective separation and biocompatibility of ATPS. This strategy involves the continuous removal of product from its site of production/fermentation broth to the opposite phase simultaneously during production. Thus, the product of interest can be extracted from the system in a single step without performing 
biomass recovery or cell disruption [30]. The composition of ATPS depended on the type of phase system constituents and their concentration, polymer molecular weight, and $\mathrm{pH}$ [26].

One of the strategies to maximize the large-scale use of ATPS is the use of optimization techniques at bench scale level in order to select the system with the best-desired performance. The most common optimization strategies employed before for ATPS include the use of univariate optimization, response surface methodology (RSM), and genetic algorithms [31]. The modern statistical and mathematical technique such as RSM offers most reliable results and been applied with a smaller number of experiments as compared to one-factor-at-a-time (OFAT) [32]. In searching optimum condition of factors for desirable responses via RSM, the $F$-value is the test for comparing the curvature variance with residual variance and probability $>F$ ( $p$-value) is the probability of seeing the observed $F$-value if the null hypothesis is true. Small probability values call for rejection of the null hypothesis and the curvature is not significant. Therefore, the larger the value of $F$ and the smaller the value of $p$, indicating that the corresponding coefficient is more significant [33].

The selection of an ideal molecular weight polymer to promote cell sustainability is primary step in extractive ATPS application. Molecular weight of PEG affects the composition of phases and the number of polymer-protein interactions via hydrophobic interactions between the chains of PEG and the hydrophobic area of the biomolecule (Abbasiliasi et al. [26]. In the present study, the growth of L. lactis Gh1 was not affected by molecular weight of all PEGs at $5-15 \%(w / w)$ and reduced at $20 \%(w / w)$. This finding contrary with Li et al. [17], who found that the growth rate of L. lactis was increased continuously with increasing molecular weight of PEG at 10\% $(w / w)$. Moreover, in our study the fact that all PEG at 20\% $(w / w)$ inhibits growth may be due to a high osmotic pressure.

In bottom phase components (salts/dextran) selection, results of this study indicated that the growth of L. lactis Gh1 was greatly affected at concentration higher than $5 \%(w / w)$ in all salts (ammonium sulphate, sodium citrate, and sodium phosphate). This finding was in line with Li et al. [17] who stated that the high salt concentration in ATPS is likely to inhibit growth of microbial cells. Gandhi and Shah [34] stated that reduced viable count of lactic acid bacteria was observed on increased exposure to salt stress, possibly owing to the injury caused by salt to the integrity of the bacterial membrane. Sensitivity of bacterial cultures to salt addition is strongly dependent on bacterial species and strain, and therefore the salt concentration can have stimulating or inhibiting effects on bacterial metabolic activity [35].

In the current investigation, the partitioning coefficients, $K$ decrease with the increase in molecular weight of PEG. The highest experimental $K$ value (1.40) was recorded in PEG2000/dextran T500 indicating the BLIS desirable in top phase of the system. This is in accordance with a study on cyclodextrins (CDs) in a PEG2000/dextranT500 system by Ng et al. [36], who reported that high concentration of PEG and dextran in an ATPS will cause the formation of precipitant at interphase that complicates the recovery of CDs. Although PEG/dextran ATPS has been applied for in situ retrieval of $\beta$-carotene [30], lipase [37], cyclodextrins [36] and pullulan [38], it has not been used in bacteriocin recovery. Furthermore, the advancement of ATPS to extractive fermentation was rarely reported for in situ bacteriocin partitioning except in two reported studies by Li et al. [39] and $\mathrm{Li}$ et al. [17]. The aim of using polymer-based compositions is to achieve a non-ionic composition compatible with ionic biomolecules with a low ionic strength. Dextran has many health benefits, and it is widely used in food industry for making bakery products, confectionery, ice cream, and frozen and dried foods [40]. Generally, PEG and dextran are preferably employed in ATPSs preparation among polymers because they perform desirable physical properties with non-toxicity [41].

In this study, reduced partitioning efficiency was observed at high orbital speed (250 rpm) due to the intermixing of both the nutrient broth and the polymer, which acts like a homogenous fermentation process during shaking as highlighted by Pandey and Banik [42]. Similar behaviors were observed in extractive fermentation for lipase production by Burkholderia cepacia where the orbital speed has significant adverse influence on the 
partition behaviors [43]. Additionally, the current findings highlighted the notable effect of $\mathrm{pH} 7$ on $\mathrm{K}$ value. It is well known the change in $\mathrm{pH}$ will influence the partitioning of the target protein which alter the phase polymer concentration, as the polymer loses/gains charge from functional groups that induce repulsion/attraction and expansion/contraction of the materials [44]. The net charge of the protein turns negative in case of higher $\mathrm{pH}$ than the isoelectric point (pI) and positive if lesser than $\mathrm{pI}$. If the $\mathrm{pH}$ is equal to $\mathrm{pI}$, net charge will be zero [20].

The results of this study suggest agitation in extractive fermentations plays a crucial role, especially in the presence of high-viscosity agents, such as PEG and dextran. Sufficient agitation and homogeneity of the phase system obtained in bioreactor as compared to shake flask may be one of the possible reasons. These properties may allow better control of environmental parameters and more efficient transportation of nutrient materials, especially oxygen [45]. Appropriate impeller speed is important because excessive agitation could have caused mechanical stress on the cells, disrupting cell morphology [46].

The overall manufacturing cost of the extraction solvents in a reusable and recyclable cycle will be reduced [47]. As regards to application as food and pharmaceutics, it includes alternative non-toxic and eco-friendly solvents [48]. Repetitive ATPS fermentation was less discussed and the data from this study provide a chance to explore this approach for production and purification of BLIS.

\section{Conclusions}

Results from this study have demonstrated that extractive fermentation using ATPS approach has the potential to improve recovery of BLIS from fermentation culture using polymers/polymers. The proposed approach significantly integrates the upstream and downstream processes for continuous production and recovery of BLIS from biomass, thus reducing the time proportion of the entire process. In addition, the versatility of ATPS and its simplicity, as only PEG and dextran T500 were used, can have an enormous industry potential to recover BLIS from fermentation broth. BLIS from L. lactis Gh1 was successfully produced and purified using a single step-extractive fermentation. The yield of BLIS increased by 0.91 times, i.e., $77.13 \%$, for ATPS composed of PEG $2000(10 \%, w / w) /$ dextran $\mathrm{T} 500(8 \%, w / w)$, optimally performed at pH 7 and agitated at $200 \mathrm{rpm}$. During the scale-up process, sustainable repetitive fermenting of cell growth up to eight times was observed in the bioreactor. Integration of L. lactis Gh1 fermentation with the downstream of BLIS purification in repetitive batch of ATPS extractive fermentation is ideally effective in terms of cost (recycling of cell for subsequent fermentation) and processing time (instant purification after each fermentation batch). In the future recommendation, Tricine SDSPAGE can be performed to check the purity and also for the estimation of the molecular weight (MW) of the partially purified BLIS.

Author Contributions: Conceptualization, S.A. and A.B.A.; Data Curation, R.J., S.A. and J.S.T.; Formal Analysis, R.J. and S.A.; Funding Acquisition, A.B.A.; Investigation, R.J. and S.A.; Methodology, R.J., S.A., and J.S.T.; Project Administration, S.A., J.S.T. and A.B.A.; Resources, S.M., M.H., B.H.L., J.S.K. and A.B.A.; Software, R.J., S.A. and J.S.T.; Supervision, S.A., J.S.T., S.M., M.H. and A.B.A.; Validation, A.B.A.; Visualization, S.M., M.H. and A.B.A.; Writing-Original Draft, R.J.; WritingReview and Editing, S.A., J.S.T. and A.B.A. All authors have read and agreed to the published version of the manuscript.

Funding: Authors acknowledge the financial supports received by Ministry of Higher Education (MOHE), Malaysia under Prototype Research Grant Scheme (PRGS/2/2015/SG05/UPM/01/2).

Institutional Review Board Statement: Not applicable.

Informed Consent Statement: Not applicable.

Data Availability Statement: The data presented in this study are available on request from the corresponding author.

Conflicts of Interest: There is no competing interest as declared by authors. 


\section{References}

1. Faour-Klingbeil, D.; Todd, E.C.D. Prevention and control of foodborne diseases in middle-east north African countries: Review of national control systems. Int. J. Environ. Res. Public Health 2020, 17, 70. [CrossRef] [PubMed]

2. Reis, J.A.U.; Paula, A.T.U.; Casarotti, S.; Penna, A.L.B.U. Lactic Acid Bacteria Antimicrobial Compounds: Characteristics and Applications. Food Eng. Rev. 2012, 4, 124-140. [CrossRef]

3. Sidek, N.L.M.; Halim, M.; Tan, J.S.; Abbasiliasi, S.; Mustafa, S.; Ariff, A.B. Stability of bacteriocin-like inhibitory substance (BLIS) produced by Pediococcus acidilactici Kp10 at different extreme conditions. Biomed. Res. Int. 2018, 2018, 5973484. [CrossRef]

4. Alvarez-Sieiro, P.; Montalbán-López, M.; Mu, D.; Kuipers, O.P. Bacteriocins of lactic acid bacteria: Extending the family. Appl. Microbiol. Biotechnol. 2016, 100, 2939-2951. [CrossRef] [PubMed]

5. Del Rocío López-Cuellar, M.; Rodríguez-Hernández, A.I.; Norberto, C.-H. LAB bacteriocin applications in the last decade. Biotechnol. Biotechnol. Equip. 2016, 30, 1039-1050. [CrossRef]

6. Song, A.A.-L.; In, L.L.A.; Lim, E.; Rahim, R.A. A review on Lactococcus lactis: From food to factory. Microb. Cell Factories 2017, 16, 55. [CrossRef]

7. Silva, C.; Silva, S.P.M.; Ribeiro, S.C. Application of Bacteriocins and Protective Cultures in Dairy Food Preservation. Front. Microbiol. 2018, 9, 594. [CrossRef]

8. Market Survey Report. 2020. Available online: https://www.marketstudyreport.com/reports/global-food-additivesmarket-research-report-2020?gclid=Cj0KCQjw3f6HBhDHARIsAD_i3D8TQIqhmx-wMp8-htMLNdP8u8cUxqzqmZ2iGz5 vLyCqWrycZx6hULQaAg9gEALw_wcB (accessed on 27 July 2021).

9. Jawan, R.; Abbasiliasi, S.; Tan, J.S.; Mustafa, S.; Halim, M.; Ariff, A.B. Influence of Culture Conditions and Medium Compositions on the Production of Bacteriocin-Like Inhibitory Substances by Lactococcus lactis Gh1. Microorganisms 2020, 8, 1454. [CrossRef]

10. Aguilar, O.; Rito-Palomares, M. Aqueous two-phase systems strategies for the recovery and characterization of biological products from plants. J. Sci. Food Agric. 2010, 90, 1385-1392. [CrossRef]

11. Muhammad Khan, B.; Cheong, K.-L.; Liu, Y. ATPS: "Aqueous two-phase system" as the "answer to protein separation" for protein-processing food industry. Crit. Rev. Food Sci. Nutr. 2019, 59, 3165-3178. [CrossRef]

12. Jamaluddin, N.; Stuckey, D.C.; Ariff, A.B.; Wong, F.W.F. Novel approaches to purifying bacteriocin: A review. Crit. Rev. Food Sci. Nutr. 2018, 58, 2453-2465. [CrossRef]

13. Dutra-Molino, J.V.; Araujo-Feitosa, V.; de Lencastre-Novaes, L.C.; Santos-Ebinuma, V.C.; Lopes, A.M.; Jozala, A.F.; Marques, D.A.V.; Malpiedi, L.P.; Pessoa, A.J. Biomolecules extracted by ATPS: Practical examples. Rev. Mex. Ing. Quimica 2014, 13, 359-377.

14. Zhao, L.; Peng, Y.-L.; Gao, J.-M.; Cai, W.-M. Bioprocess intensification: An aqueous two-phase process for the purification of C-phycocyanin from dry Spirulina platensis. Eur. Food Res. Technol. 2013, 238, 451-457. [CrossRef]

15. Sabo, S.; Lopes, A.; Santos-Ebinuma, V.; Rangel-Yagui, C.; Oliveira, R. Bacteriocin partitioning from a clarified fermentation broth of Lactobacillus plantarum ST16Pa in aqueous two-phase systems with sodium sulfate and choline-based salts as additives. Process. Biochem. 2018, 66, 212-221. [CrossRef]

16. Banik, R.M.; Santhiagu, A.; Kanari, B.; Sabarinath, C.; Upadhyay, S. Technological aspects of extractive fermentation using aqueous two-phase systems. World J. Microbiol. Biotechnol. 2003, 19, 337-348. [CrossRef]

17. Li, C.; Ouyang, F.; Bai, J. Extractive cultivation of Lactococcus lactis using a polyethylene glycol $/ \mathrm{MgSO}_{4} \cdot 7 \mathrm{H}_{2} \mathrm{O}$ aqueous two-phase system to produce nisin. Biotechnol. Lett. 2000, 22, 843-847. [CrossRef]

18. Ratanapongleka, K. Recovery of Biological Products in Aqueous Two Phase Systems. Int. J. Chem. Eng. Appl. 2010, 1, 191-198. [CrossRef]

19. Iqbal, M.; Tao, Y.; Xie, S.; Zhu, Y.; Chen, D.; Wang, X.; Huang, L.; Peng, D.; Sattar, A.; Shabbir, M.A.B.; et al. Aqueous two-phase system (ATPS): An overview and advances in its applications. Proced. Online 2016, 18, 18. [CrossRef]

20. Raja, S.; Murty, V.R.; Thivaharan, V.; Rajasekar, V.; Ramesh, V. Aqueous Two Phase Systems for the Recovery of Biomolecules-A Review. Sci. Technol. 2011, 1, 7-16. [CrossRef]

21. Raja, S.; Murty, V.R. Development and Evaluation of Environmentally Benign Aqueous Two Phase Systems for the Recovery of Proteins from Tannery Waste Water. ISRN Chem. Eng. 2012, 2012, 290471. [CrossRef]

22. Abbasiliasi, S.; Tan, J.S.; Ibrahim, T.A.T.; Ramanan, R.N.; Vakhshiteh, F.; Mustafa, S.; Ling, T.C.; Rahim, R.A.; Ariff, A.B. Isolation of Pediococcus acidilactici Kp10 with ability to secrete bacteriocin-like inhibitory substance from milk products for applications in food industry. BMC Microbiol. 2012, 12, 260. [CrossRef]

23. Jawan, R.; Abbasiliasi, S.; Mustafa, S.; Kapri, M.R.; Halim, M.; Ariff, A.B. In Vitro Evaluation of Potential Probiotic Strain Lactococcus lactis Gh1 and Its Bacteriocin-Like Inhibitory Substances for Potential Use in the Food Industry. Probiotics Antimicrob. Proteins 2021, 13, 422-440. [CrossRef] [PubMed]

24. Abbasiliasi, S.; Ramanan, R.N.; Tengku Azmi, T.I.; Shuhaimi, M.; Mohammad, R.; Ariff, A.B. Partial characterization of antimicrobial compound produced by Lactobacillus paracasei LA 07, a strain isolated from Budu. Minerva Biotechnol. 2010, 22, 75-82.

25. Jawan, R.; Abbasiliasi, S.; Tan, J.; Kapri, M.; Mustafa, S.; Halim, M.; Ariff, A. Evaluation of the Estimation Capability of Response Surface Methodology and Artificial Neural Network for the Optimization of Bacteriocin-Like Inhibitory Substances Production by Lactococcus lactis Gh1. Microorganisms 2021, 9, 579. [CrossRef] 
26. Abbasiliasi, S.; Tan, J.S.; Ibrahim, T.A.T.; Kadkhodaei, S.; Ng, H.S.; Vakhshiteh, F.; Ajdari, Z.; Mustafa, S.; Ling, T.C.; Rahim, R.A.; et al. Primary recovery of a bacteriocin-like inhibitory substance derived from Pediococcus acidilactici Kp10 by an aqueous two-phase system. Food Chem. 2014, 151, 93-100. [CrossRef]

27. Bernbom, N.; Licht, T.R.; Brogren, C.-H.; Jelle, B.; Johansen, A.H.; Badiola, I.; Vogensen, F.K.; Nørrung, B. Effects of Lactococcus lactis on Composition of Intestinal Microbiota: Role of Nisin. Appl. Environ. Microbiol. 2006, 72, 54-58. [CrossRef] [PubMed]

28. Aziz, N.F.H.A.; Abbasiliasi, S.; Ng, Z.J.; Abu Zarin, M.; Oslan, S.N.; Tan, J.S.; Bin Ariff, A. Recovery of a Bacteriocin-Like Inhibitory Substance from Lactobacillus bulgaricus FTDC 1211 Using Polyethylene-Glycol Impregnated Amberlite XAD-4 Resins System. Molecules 2020, 25, 5332. [CrossRef] [PubMed]

29. Sinha, J.; Dey, P.K.; Panda, T. Aqueous two-phase: The system of choice for extractive fermentation. Appl. Microbiol. Biotechnol. 2000, 54, 476-486. [CrossRef]

30. Chavez-Santoscoy, A.; Benavides, J.; Vermaas, W.; Rito-Palomares, M. Application of Aqueous Two-Phase Systems for the Potential Extractive Fermentation of Cyanobacterial Products. Chem. Eng. Technol. 2010, 33, 177-182. [CrossRef]

31. Torres-Acosta, M.A.; Mayolo-Deloisa, K.; González-Valdez, J.; Rito-Palomares, M. Aqueous Two-Phase Systems at Large Scale: Challenges and Opportunities. Biotechnol. J. 2019, 14, e1800117. [CrossRef]

32. Singh, V.; Haque, S.; Niwas, R.; Srivastava, A.; Pasupuleti, M.; Tripathi, C.K.M. Strategies for Fermentation Medium Optimization: An In-Depth Review. Front. Microbiol. 2017, 7, 2087. [CrossRef]

33. Bayraktar, E. Response surface optimization of the separation of dl-tryptophan using an emulsion liquid membrane. Process. Biochem. 2001, 37, 169-175. [CrossRef]

34. Gandhi, A.; Shah, N.P. Effect of salt on cell viability and membrane integrity of Lactobacillus acidophilus, Lactobacillus casei and Bifidobacterium longum as observed by flow cytometry. Food Microbiol. 2015, 49, 197-202. [CrossRef]

35. Medved'ová, A.; Šipošová, P.; Mančušková, T.; Valík, L'. The Effect of Salt and Temperature on the Growth of Fresco Culture. Fermentation 2018, 5, 2. [CrossRef]

36. Ng, H.S.; Ooi, C.W.; Mokhtar, M.N.; Show, P.L.; Ariff, A.; Tan, J.S.; Ng, E.-P.; Ling, T.C. Extractive bioconversion of cyclodextrins by Bacillus cereus cyclodextrin glycosyltransferase in aqueous two-phase system. Bioresour. Technol. 2013, 142, 723-726. [CrossRef]

37. Ooi, C.W.; Hii, S.L.; Kamal, S.M.M.; Ariff, A.; Ling, T.C. Extractive fermentation using aqueous two-phase systems for integrated production and purification of extracellular lipase derived from Burkholderia pseudomallei. Process. Biochem. 2011, 46, 68-73. [CrossRef]

38. Badhwar, P.; Kumar, P.; Dubey, K.K. Extractive Fermentation for Process integration and amplified pullulan production by A. pullulans in Aqueous Two Phase Systems. Sci. Rep. 2019, 9, 32. [CrossRef] [PubMed]

39. Li, C.; Bai, J.; Li, W.; Cai, Z.; Ouyang, F. Optimization of Conditions for Bacteriocin Extraction in PEG/Salt Aqueous Two-Phase Systems Using Statistical Experimental Designs. Biotechnol. Prog. 2001, 17, 366-368. [CrossRef]

40. Bhavani, A.L.; Nisha, J. Dextran-The polysaccharide with versatile uses. Int. J. Pharma. Biol. Sci. 2010, 1, 569-573.

41. Kula, M.R.; Korner, K.H.; Hustedt, H. Purification of Enzymes by Liquid-Liquid Extraction. In Reaction Engineering. Advances in Biochemical Engineering; Fechter, A., Ed.; Springer: Berlin/Heidelberg, Germany, 1982; pp. 73-118.

42. Pandey, S.; Banik, R. Extractive fermentation for enhanced production of alkaline phosphatase from Bacillus licheniformis MTCC 1483 using aqueous two-phase systems. Bioresour. Technol. 2011, 102, 4226-4231. [CrossRef]

43. Show, P.L.; Tan, C.P.; Anuar, M.S.; Ariff, A.; Yusof, Y.A.; Chen, S.K.; Ling, T.C. Extractive fermentation for improved production and recovery of lipase derived from Burkholderia cepacia using a thermoseparating polymer in aqueous two-phase systems. Bioresour. Technol. 2012, 116, 226-233. [CrossRef] [PubMed]

44. Saravanan, S.; Rao, J.R.; Nair, B.U.; Ramasami, T. Aqueous two-phase poly(ethylene glycol)-poly(acrylic acid) system for protein partitioning: Influence of molecular weight, $\mathrm{pH}$ and temperature. Process. Biochem. 2008, 43, 905-911. [CrossRef]

45. Wang, S.J.; Zhong, J.J. Bioreactor engineering. In Bioprocessing for Value-Added Products from Renewable Resources; Yang, S.T., Ed.; Elsevier: Amsterdam, The Netherlands, 2006; pp. 131-161.

46. Marques, D.D.A.V.; Santos-Ebinuma, V.C.; Pessoa, A.; Porto, A.L.F.; Torres, B.R.; Converti, A. Effect of aeration and agitation on extractive fermentation of clavulanic acid by using aqueous two-phase system. Biotechnol. Prog. 2016, 32, 1444-1452. [CrossRef]

47. Sankaran, R.; Manickam, S.; Yap, Y.J.; Ling, T.C.; Chang, J.-S.; Show, P.L. Extraction of proteins from microalgae using integrated method of sugaring-out assisted liquid biphasic flotation (LBF) and ultrasound. Ultrason. Sonochem. 2018, 48, 231-239. [CrossRef] [PubMed]

48. Khoo, K.S.; Chew, K.W.; Ooi, C.W.; Ong, H.C.; Ling, T.C.; Show, P.L. Extraction of natural astaxanthin from Haematococcus pluvialis using liquid biphasic flotation system. Bioresour. Technol. 2019, 290, 121794. [CrossRef] [PubMed] 